\begin{tabular}{lcl}
\hline Bentham OPEN & Open Medicine Journal \\
CrossMark & Content list available at: www.benthamopen.com/MEDJ/ \\
\hline
\end{tabular}

RESEARCH ARTICLE

\title{
Co-occurring Depression, Chronic Pain and Substance Use Disorders in People with Hepatitis $\mathrm{C}$
}

\author{
Elizabeth Chereji ${ }^{1}$, Shira Kern ${ }^{1}$, Bret Fuller ${ }^{2,3}$, Benjamin J. Morasco, ${ }^{2,3}$, Alissa Phelps ${ }^{2}$ and Peter \\ Hauser ${ }^{1,4,5,6, *}$ \\ ${ }^{I}$ Mental Health, Long Beach VA Medical Center, CA, 90822, USA \\ ${ }^{2}$ Mental Health and Clinical Neurosciences Division, VA Portland Health Care System, Portland, USA \\ ${ }^{3}$ Department of Psychiatry, Oregon Health \& Science University, Portland, OR, USA \\ ${ }^{4}$ VISN 22 Network Office, Long Beach, California, USA \\ ${ }^{5}$ Department of Psychiatry and Human Behavior, University of California-Irvine, Irvine, California, USA \\ ${ }^{6}$ Department of Psychiatry, University of California San Diego, San Diego, California, USA
}

Received: February 6, 2015

Revised: March 20, 2016

Accepted: June 11, 2016

\begin{abstract}
Chronic infection with Hepatitis C virus (HCV) is common and can result in serious and sometimes fatal liver complications. The impact of HCV on the liver can be further complicated by medical and psychological comorbidities. Depression, substance use, and pain syndromes are frequent co-morbid conditions in people with HCV and diminish functioning, quality of life, and treatment compliance. Understanding the underlying biological mechanisms of these comorbid conditions within the context of $\mathrm{HCV}$ may help elucidate factors contributing to their co-occurrence, perhaps mediated via pro-inflammatory cytokines. The current review provides a synthesis of the literature on depression, substance use disorders and chronic pain in the presence of HCV. The review includes studies conducted with both veteran and civilian populations. The implications for assessment and antiviral treatment of HCV will be considered.
\end{abstract}

Keywords: Depression, Hepatitis C, Pain, Substance Use.

\section{INTRODUCTION}

Approximately $2 \%$ of Americans are chronically infected with Hepatitis $\mathrm{C}$ virus (HCV), making it the most common blood-borne disease in the United States [1]. Among people infected with HCV approximately 20-25\% will develop cirrhosis and as many as 3-4\% will develop hepatocellular carcinoma [2, 3]. HCV is often accompanied by significant medical and psychiatric co-morbidities that can complicate the course of illness. Some of the more common co-occurring disorders that have received empirical attention include depression, substance use disorders (SUDs), and chronic pain.

The prevalence of depression-related diagnoses has been reported to be higher among individuals with $\mathrm{HCV}$ as compared with the general population. It is estimated that $20 \%$ to $40 \%$ of people with HCV experience clinically significant symptoms of depression [4 - 9]. Interferon-alpha (IFN) has been the most common treatment for HCV (prior to the advent of IFN-free treatments) and there are numerous neuropsychiatric consequences of IFN treatment, including depression. Depressive symptoms that precede the start of antiviral therapy can be significantly aggravated by treatment with IFN [10 - 13]. Also, IFN-induced depressive symptoms, if undiagnosed and left untreated, can have a considerable adverse impact on adherence to and completion of antiviral treatment $[11,14]$.

\footnotetext{
* Address correspondence to this author at the 300 Oceangate, Suite 700, Long Beach, California 90802, USA; Tel: 562-826-8000. x2629; E-mail: peter.hauser2@va.gov
} 
Substance use disorders are another important comorbidity to consider in individuals with HCV. Alcohol usedisorders (AUDs) are commonly found among HCV patients [6, 15, 16], can further compromise hepatic function [17 - 23], and are a major reason for healthcare providers excluding people from antiviral treatment [24 - 26]. Intravenous drug use (IDU) not only complicates HCV progression and treatment but now accounts for the vast majority of $\mathrm{HCV}$ infection; the sharing of drug injection equipment places users at very high risk of contracting the virus $[15,16,23,27]$. Overall, SUDs are the primary cause of HCV transmission, significantly increase the risk of HCV infection (even among people without IDU who have AUD), and are often considered the basis for exclusion from antiviral treatment $[16,25,27,28]$.

The prevalence of pain-related diagnoses is also higher among individuals with HCV compared to those without the virus [29 - 32]. Pain-related diagnoses include musculoskeletal disorders as well as arthritis and fibromyalgia [33, 34]. This association may be attributable to a variety of complex etiological factors, including psychological, social, and/or biological variables [35 - 37].

In this review, studies that investigate the relationships among depression, SUD, and chronic pain in people with $\mathrm{HCV}$ will be examined. The interactions among these comorbidities within the context of HCV infection provide an opportunity to elucidate the underlying biological mechanisms of these conditions. Furthermore, these conditions can impact factors that are critical to the health of individuals with $\mathrm{HCV}$, including health care utilization, treatment adherence, and quality of life.

\section{Hepatitis C and Depression}

The prevalence of depression is higher among individuals with HCV as compared to those without the virus [15, 38]. Increased rates of depression among HCV patients may be attributable to a variety of factors that can be examined from three perspectives:

1. depression associated with HCV and related complications,

2. associated psychosocial variables that may confer increased risk of depression, and

3. IFN-induced depression.

Tables 1-4 presents selected studies related to HCV and depression.

Table 1. Depression, HCV and health related quality of life (HRQOL).

\begin{tabular}{|c|c|c|c|c|}
\hline References & $\begin{array}{l}\text { Sample Size and } \\
\text { Characteristics }\end{array}$ & Purpose and Design & $\begin{array}{l}\text { Rating Scales for } \\
\text { Depression, Mood } \\
\text { and HRQOL }\end{array}$ & Outcome \\
\hline Singh et al. [39] & $\begin{array}{l}82 \text { liver transplant candidates } \\
\text { with and without HCV (42 } \\
\text { patients with HCV and } 40 \text { with } \\
\text { other liver diseases) from the } \\
\text { Liver Transplant Center a VA } \\
\text { Hospital }\end{array}$ & $\begin{array}{l}\text { Prospective assessment (4 years) } \\
\text { of quality of life, psychological } \\
\text { distress, depression and coping. }\end{array}$ & $\begin{array}{l}\text { Beck depression } \\
\text { Inventory (BDI), } \\
\text { Ways of Coping } \\
\text { scale, (WOCS), } \\
\text { Profile of Mood } \\
\text { States (POMS) }\end{array}$ & $\begin{array}{l}\text { Patients with } \\
\text { HCV were significantly more } \\
\text { depressed than patients without } \mathrm{HCV} \text {. }\end{array}$ \\
\hline Lee et al. [38] & $\begin{array}{l}500 \text { patients with HCV referred } \\
\text { to a hospital Hepatology clinic }\end{array}$ & $\begin{array}{l}\text { Retrospective medical record } \\
\text { review of HCV, liver disease, and } \\
\text { comorbidities }\end{array}$ & $\begin{array}{l}\text { Chart diagnoses in } \\
\text { medical records }\end{array}$ & $\begin{array}{l}24 \% \text { of patients had chart diagnoses of } \\
\text { depression; two thirds of these } \\
\text { individuals were prescribed } \\
\text { antidepressants. }\end{array}$ \\
\hline Foster et al. [40] & $\begin{array}{l}76 \text { patients with } \mathrm{HCV} \text { attending } \\
\text { a hospital outpatient clinic }\end{array}$ & $\begin{array}{l}\text { Prospective assessment ( } 3 \\
\text { months) of the effects of } \mathrm{HCV} \\
\text { infection in the absence of } \\
\text { cirrhosis, on patients' quality of } \\
\text { life. }\end{array}$ & $\begin{array}{l}\text { Short Form-36 } \\
\text { (SF-36) }\end{array}$ & $\begin{array}{l}\text { Patients with chronic HCV infection } \\
\text { had marked reduction in HRQOL; } \\
\text { physical symptoms may contribute } \\
\text { directly to this reduction. }\end{array}$ \\
\hline Dwight et al. [5] & $\begin{array}{l}55 \text { patients with } \mathrm{HCV} \text { from a } \\
\text { Hepatology clinic at a } \\
\text { University hospital }\end{array}$ & $\begin{array}{l}\text { Prospective assessment (1 year) } \\
\text { to examine how fatigue and } \\
\text { functional disability correlate } \\
\text { with depression severity }\end{array}$ & $\begin{array}{l}\text { Psychiatric } \\
\text { Interviews }\end{array}$ & $\begin{array}{l}\text { Severity of depressive symptoms was } \\
\text { highly correlated with fatigue severity } \\
\text { and disability. However, measures of } \\
\text { hepatic disease severity and interferon } \\
\text { treatment were not correlated with } \\
\text { severity of depression }\end{array}$ \\
\hline
\end{tabular}




\begin{tabular}{|c|c|c|c|c|}
\hline References & $\begin{array}{l}\text { Sample Size and } \\
\text { Characteristics }\end{array}$ & Purpose and Design & $\begin{array}{l}\text { Rating Scales for } \\
\text { Depression, Mood } \\
\text { and HRQOL }\end{array}$ & Outcome \\
\hline $\begin{array}{l}\text { McHutchinson et al. } \\
{[10]}\end{array}$ & $\begin{array}{l}912 \text { patients with } \mathrm{HCV} \text { in a } \\
\text { multicenter clinical trial of } \\
\text { combination therapy for } \mathrm{HCV} .\end{array}$ & $\begin{array}{l}\text { Prospective evaluation ( } 24 \text { or } 48 \\
\text { week treatment period) of the } \\
\text { effect of HCV as well as antiviral } \\
\text { therapy on health-related quality } \\
\text { of life (HRQOL) and work } \\
\text { functioning. }\end{array}$ & $\begin{array}{l}\text { HRQOL, SF-36, } \\
\text { Self-report }\end{array}$ & $\begin{array}{l}\text { Patients with HCV had low HRQOL } \\
\text { that improved in those were } \\
\text { successfully treated and who achieved } \\
\text { SVR. }\end{array}$ \\
\hline El-Serag et al. [15] & $\begin{array}{l}33,824 \text { Veterans infected with } \\
\text { HCV and over one million } \\
\text { Veterans not infected with } \\
\text { HCV hospitalized in VA } \\
\text { hospitals between 1992-1999 }\end{array}$ & $\begin{array}{l}\text { Retrospective chart review of } \\
\text { psychiatric and substance use } \\
\text { disorders. }\end{array}$ & $\begin{array}{l}\text { Chart diagnoses in } \\
\text { medical records }\end{array}$ & $\begin{array}{l}\text { Patients with HCV were more likely to } \\
\text { have depression than non HCV- } \\
\text { infected controls ( } 49.5 \% \text { vs } 39.1 \%)\end{array}$ \\
\hline $\begin{array}{l}\text { Gallegos-Orozco } \\
{[43]}\end{array}$ & $\begin{array}{l}157 \text { patients with } \mathrm{HCV} \\
\text { attending a Hepatology clinic }\end{array}$ & $\begin{array}{l}\text { Prospective assessment (12 } \\
\text { months) of HRQOL, depression, } \\
\text { and illness understanding }\end{array}$ & $\begin{array}{l}\text { SF-36 Zung Rating } \\
\text { Scale for } \\
\text { Depression } \\
\text { (ZRDS). }\end{array}$ & $\begin{array}{l}\text { Patients had significantly lower } \\
\text { HRQOL scores associated with } \\
\text { depression and poor illness } \\
\text { understanding. }\end{array}$ \\
\hline Golden et al. [7] & $\begin{array}{l}90 \text { patients with HCV } \\
\text { scheduled for IFN- based } \\
\text { therapy at a University } \\
\text { Hospital Hepatology Clinic }\end{array}$ & $\begin{array}{l}\text { Cross sectional assessment of } \\
\text { Major depressive Disorder } \\
\text { (MDD), anxiety disorders and } \\
\text { associated risk factors prior to } \\
\text { IFN- based therapy }\end{array}$ & $\begin{array}{l}\text { Structural Clinical } \\
\text { Interview for the } \\
\text { DSM (SCID) }\end{array}$ & $\begin{array}{l}28 \% \text { had a 1-month prevalence of } \\
\text { MDD; } 36 \% \text { had a lifetime diagnosis of } \\
\text { any depressive disorder. Depression } \\
\text { was associated with poorer work and } \\
\text { social adjustment, higher illness related } \\
\text { stigma, high levels of physical } \\
\text { symptoms, and more cognitive } \\
\text { concerns. }\end{array}$ \\
\hline Nelligan et al. [8] & $\begin{array}{l}881 \text { Veterans with HCV from } \\
\text { VA Hospital Hepatology Clinic }\end{array}$ & $\begin{array}{l}\text { Prospective cohort study ( } 4 \\
\text { years) to assess the prevalence } \\
\text { and severity of depression }\end{array}$ & BDI & $\begin{array}{l}\text { Approximately one third of Veterans } \\
\text { with HCV endorsed significant } \\
\text { depressive symptoms, independent of } \\
\text { ongoing antidepressant treatment. }\end{array}$ \\
\hline
\end{tabular}

${ }^{1}$ Refer to Appendix A for list of measures associated with abbreviations.

Notes:

-Original studies with $>15$ subjects with HCV were included in table.

-Studies with non-human subjects omitted.

-Literature Review studies were omitted.

\section{Depression Associated with HCV and Related Complications}

Several studies have examined the impact of chronic HCV on mood. Individuals who have end stage liver disease (ESLD) caused by HCV are more likely to manifest symptoms of depression as compared with those who have ESLD unrelated to HCV [39]. HCV infection, even in the absence of cirrhosis, has been associated with diminished quality of life and quality of life has been reported to improve when sustained viral response (SVR) is achieved [40, 41]. Several studies report that individuals with HCV have significantly lower quality of life relative to healthy population controls [40, 42, 43]. In a study of $157 \mathrm{HCV}$ patients with no previous history of antiviral treatment, approximately $60 \%$ had significant symptoms of depression. Furthermore, HCV patients with depression demonstrated lower quality of life scores than those without depressive symptoms [43]. While the specific reasons for the association between depression and quality of life are unclear, possible explanations could include the emotional distress associated with functional impairment related to chronic HCV. Individuals with HCV often have high levels of fatigue and pain, which may affect mood or be attributable to somatic symptoms of depression [5, 9, 30]. Another potential explanation for depressive symptoms is central nervous system involvement in HCV. The virus may directly impact the central nervous system in a manner that can influence mood, including alterations in dopamine and serotonin neurotransmission [44].

\section{HCV, Depression, and Common Psychosocial Correlates}

Psychosocial factors that commonly co-occur with HCV can increase risk of depression. Substance use disorders (to be discussed in depth later in this review) commonly co-occur with HCV and are also a risk factor for depression. SUDs frequently co-occur with psychiatric disorders and are more common among people with schizophrenia and mood disorders, regardless of HCV status [45 - 49]. As such, SUDs alone are a risk factor for other psychiatric disorders among individuals with HCV. Socioeconomic variables can also serve as significant risk factors, as rates of $\mathrm{HCV}$ and depression are higher in economically disadvantaged populations [50, 51]. Identifying risk factors for depression as well as screening for depression is particularly important prior to the start of treatment; pre-existing depression can worsen during the course of treatment with interferon, and greater depression symptom severity increases the likelihood of 
developing IFN-induced depression [5, 11, 52].

\section{Interferon-induced Depression}

Until recently, IFN has been the primary component of antiviral treatment. Initially, regular IFN was given as monotherapy by injection 3-5 times per week and SVR was relatively poor. Pegylated formulations of IFN allowed once per week injections and dramatically increased SVR, particularly when given in combination with ribavirin. Existing published research suggests that patients with HCV who are treated with IFN commonly have significant depressive symptoms, usually within the first 3 months of treatment $[11,53,54]$. The prevalence of IFN-induced depression in HCV patients varies across studies and ranges from $16 \%$ to nearly $40 \%$; the recorded rates of depression are dependent on use and frequency of use of depression screening instruments [11, 12, 41, 55 - 57].

Multiple proposed mechanisms exist by which IFN therapy may result in depressive symptoms [54]. Interferon may increase serotonin reuptake and decrease serotonin concentrations in the brain, which can result in depressed mood [58, 59]. An increase in pro-inflammatory cytokines due to IFN therapy has been associated with depressive symptoms [60, 61], tryptophan (a precursor of serotonin) depletion [62], and immune response activation that can adversely affect brain structures [63]. The increased risk of IFN-induced depressive symptoms can result in decreased antiviral treatment adherence, increased discontinuation rates, and decreased completion rates if depression is not promptly diagnosed and treated with antidepressants $[11,14]$.

Given the very high rates of IFN-induced depression and the potential impact on treatment compliance, clinicians have sought ways to ameliorate depressive side effects by using antidepressant medications. Initial case reports and case series show that various antidepressant medications (selective serotonin reuptake inhibitors [SSRIs], imipramine and bupropion) are effective in treating IFN-induced depression [64 - 68]. Subsequent studies that prospectively assessed depressive symptoms in Veterans with HCV on IFN-based antiviral therapy showed that SSRIs were effective in treating IFN-induced depression, thus allowing continuation and completion of antiviral therapy [11, 69]. Prevention of IFN-induced depression by using antidepressants prophylactically has been shown to be effective in individuals who previously had IFN-induced depression [13, 51, 70 - 72]. A retrospective case series that compared Veterans with HCV and no pre-existing depression to those with $\mathrm{HCV}$ and pre-existing depression treated with antidepressants prior to beginning antiviral therapy did not find differences in completion rates or SVR between groups [73]. Also, a recent randomized double-blind placebo-controlled study that monitored patients for IFN-induced depression after antiviral therapy was initiated and randomized them to either citalopram or placebo showed benefits in alleviating depressive symptoms with citalopram but not placebo [74]. However, other studies assessing the benefit of prophylactic use of SSRIs showed no benefit for SSRIs when compared to placebo in preventing IFN-induced depression, but SSRIs may have blunted the magnitude of depressive symptomatology $[68,75,76]$.

Overall, depressive symptomatology is common among patients with HCV and may be exacerbated by other psychosocial variables and IFN-based treatments. However, studies suggest that management of depressive symptoms during antiviral treatment is easily achieved and therefore depressive symptoms should not be used as a reason not to treat people who have HCV.

\section{Hepatitis C and Substance Use Disorders}

Substance use disorders are a well-known comorbidity among individuals with Hepatitis C [6, 7, 15, 16]. AUD and IDU in particular are common sources of adversity among this population and directly affect rates of infection and disease severity. While alcohol is known to impact functioning of the liver, central nervous system, and gut [77 - 81], $\mathrm{HCV}$ can further compound the adverse health consequences of drinking. Similar to comorbid depression, SUD can impact quality of life, treatment viability, and outcomes. Tables $\mathbf{5}$ and $\mathbf{6}$ present selected research related to HCV and SUD.

\section{Alcohol Use and Disease Progression in HCV}

Alcohol use is extremely common among patients with Hepatitis $\mathrm{C}$ and is particularly problematic for this population $[6,15]$. The prevalence of $\mathrm{HCV}$ is 7 to 10 fold higher in individuals with an AUD than in the general population, and individuals with HCV compose up to $43 \%$ of patients with liver disease and co-occurring AUDs [23, 82]. Also as many as $60 \%$ of people with HCV have a history of alcohol use and over half of patients presenting to hepatology clinics report drinking alcohol in the past year [6, 82]. Heavy or excessive alcohol consumption can impact liver disease progression and worsen the outcome of $\operatorname{HCV}[20,23,83]$; it significantly exacerbates the development of 
cirrhosis, hepatocellular carcinoma, and ESLD [17, 18, 20 - 22, 83 - 87].

Overall, alcohol use is thought to act synergistically to accelerate liver injury and can contribute to the development of fibrosis and cirrhosis in this population, even in moderate (20 to 80 grams per day) and lower amounts ( 1 to 30 grams per day) [17, $19-23,85]$. Reducing or abstaining from alcohol consumption can slow the progression of liver disease and reduce or eliminate the negative health consequences of alcohol use in HCV-infected individuals [88]. A summary of the literature on this relationship can be found in Table 5.

\section{Injection Drug Use and Other Substances with HCV Infection}

Intravenous drug use is a leading cause of HCV infection and currently accounts for the majority of HCV infection in United States and other developed countries [89]. Approximately 80-95\% of injection drug users have HCV [90]. IDU accounts for $60 \%$ to $90 \%$ of new HCV infections in the United States [23, 89 - 91].

$\mathrm{HCV}$ risk among injection drug users is due to sharing drug preparation and injection equipment. The risk of infection among individuals who share needles or other equipment is between $50 \%$ and $80 \%$ after one year, and nearly $100 \%$ after eight years $[23,92,93]$. As compared with uninfected injection drug users, injection drug users with HCV are more likely to inject for longer periods of time, use heroin and crack cocaine, and consume more alcohol [94 - 96]. Injection drug users with HCV who are homeless and use other drugs are more likely to screen positive for problem drinking behaviors, and are likely to report an increase in risk-taking behaviors that could potentially lead to infection or reinfection [55, 95]. Use of substances such as heroin, crack cocaine, and alcohol is also associated with HCV infection, independent of IDU exposure; rates of HCV among people with non-IDU SUD have been reported to be as high as $29 \%$ $[23,96]$.

\section{Treatment of Individuals With HCV and SUD Comorbidities}

Treatment of HCV among people with SUD is a long-standing and complicated issue. Co-occurring SUDs were previously considered a contraindication for antiviral treatment, and alcohol use has been reported to be the most common contraindication for antiviral therapy $[25,97,98]$. Some studies suggest that patients with SUD were subjected to social bias and preexisting expectations for failure during the course of antiviral therapy [24, 99]. Common reasons for exclusion included poor adherence to treatment regimens, greater risk of antiviral treatment side effects (such as depression), higher risk for reinfection (particularly among adults with a history of IDU), and the lack of urgency for treatment initiation in this population [89]. Overall, these issues were thought to not only complicate the treatment process but also decrease the likelihood of successful treatment outcomes.

However, more recent studies suggest that antiviral treatment is viable in this population and treatment outcomes do not differ significantly between $\mathrm{HCV}$-infected individuals with and without a history of SUD. One retrospective chart review of HCV-infected Veterans with and without SUDs suggests that compliance and rates of SVR are similar [100].

Other studies suggest that SUDs/AUDs can be well managed and should not automatically exclude patients from antiviral treatment $[55,89,101]$. One study comparing HCV-infected people with psychiatric disorders, methadone substitution, and former drug addiction to controls without psychiatric/drug problems found similarities in SVR rates [102]. This suggests treatment can be effective, even in high-risk populations. Studies suggest that patients with HCV infection and SUDs who attend a substance abuse treatment program are more likely to receive and complete HCV treatment when compared with patients who never attended treatment [91, 96]. Similarly, these individuals are more likely to abstain from alcohol, are less likely to reinitiate IDU, and are more likely remain sober six months posttreatment $[96,103]$. Interventions that focus on different aspects of recovery from alcohol use, including motivational enhancement, have been found to promote abstinence among individuals with HCV [104].

Early notification and education provided to patients who are newly diagnosed with HCV may increase their motivation for antiviral treatment initiation, enhance positive healthy lifestyle transitions, promote abstinence, and improve antiviral treatment compliance [96]. Studies indicate that injection drug users who are aware of their HCV status tend to engage in fewer HCV risk-related behaviors than those who do not know their status [94]. On the other hand, studies suggest that knowledge of alcohol-related complications of HCV does not directly result in reduction of alcohol consumption within this population [95, 105]. As such, approaches to reduce harmful drinking may require careful consideration and should address underlying reasons for continued alcohol use, as opposed to simply providing information on alcohol-related complications [95].

Overall, comprehensive HCV care requires prevention counseling and education, screening for risk behaviors, 
assessment and treatment of psychiatric co-morbidities, care management of substance abuse treatment services, as well as providing social support [91, 92, 106].

\section{Hepatitis C and Pain}

Chronic pain affects more than one-third of U.S. adults and is often associated with medical and psychiatric comorbidity [107], decreased quality of life [108], and increased medical utilization [109]. Studies suggest that the etiology of chronic pain and the transition from acute to chronic pain are associated with various biopsychosocial factors. [110]. Table 7 identifies studies investigating the association between pain and HCV.

Pain is a major concern for individuals with liver disease. The prevalence of pain is particularly high in people with HCV (30-40\%) and chronic liver disease (17\% to $24 \%$ ), with some estimates ranging as high as $50 \%$ to $81 \%$ in this population $[29,30,32,35,111,112]$. Pain intensity varies but in some cases has been reported to be moderate to severe in over $50 \%$ of patients; pain poses a significant challenge for individuals with HCV and is associated with diminished quality of life and impaired role functioning [112].

\section{Pain Diagnoses in Patients with $\mathrm{HCV}$}

Musculoskeletal pain diagnoses are significantly more common in individuals with HCV than in non-infected comparison groups [30, 32,]. Other common symptoms include sleep disturbance, headache, and fatigue [113]. Common pain-related diagnoses include arthritis (61\%), low back pain, (63\%), and joint or neck pain $(75 \%)$; 50\% of individuals report at least two or three pain diagnoses and up to $22 \%$ have reported four or more [36].

In addition to chronic pain symptoms, pain-related diagnoses such as peripheral neuropathy, fibromyalgia syndrome, and other rheumatic symptoms (arthralgia, myalgia, and paresthesia) are also more prevalent in individuals with HCV [30 - 33, 113 - 115]. Across studies, fibromyalgia was reported in $18.9 \%$ to $57 \%$ of patients with HCV [34, 113].

\section{Etiological Factors for Pain and Pain Severity}

The cause of pain in people with HCV is unclear; potential etiological factors include HCV disease-related variables and psychosocial factors, including psychiatric and substance use disorder comorbidities [35]. Abnormalities in immune functioning and pro-inflammatory cytokines may also play a role in HCV pain-related diagnoses. One study found similarities in cytokine elevations that develop in fibromyalgia and those thought to be related to the immune response to HCV [115]. Although the exact relationship between these conditions has yet to be determined, it is believed that pro-inflammatory cytokines may play a crucial role.

Psychosocial variables, particularly depression severity, may also account for increases in pain severity, pain intensity, and effects on pain functioning [35]. These variables, including depression and substance abuse, are not only common among individuals with $\operatorname{HCV}[6,7,31]$ but are also highly associated with chronic pain independent of HCV status $[36,107,116,117]$.

\section{Quality of Life}

Pain-related comorbidities contribute to a significantly greater number of symptoms and behaviors known to impair physical functioning and quality of life in people with $\mathrm{HCV}[31,37]$. Chronic pain interferes with daily activities, living skills, and relationships; it affects the experience of HCV, increases the endorsement of HCV-related symptoms, and increases physical impairment $[31,34,35,111]$. Even minimal levels of pain warrant intervention, as the recognition and management of pain conditions with HCV will likely improve quality of life in this population [31, 120]. For those with pain and co-morbid depression, treating depressive symptomatology may improve the perception of pain and thus improve quality of life [34, 35].

\section{Healthcare Utilization and Treatment for Pain}

People who have HCV and chronic pain comorbidities are more frequent users of medical services than people with HCV who do not have chronic pain. The co-occurrence of pain is related to higher utilization of healthcare and disability services among these individuals $[31,111,112]$. HCV and co-occurring pain has been associated with greater number of inpatient medical and psychiatric hospitalizations as well as a higher number of outpatient encounters with providers of primary care, physical therapy, and occupational therapy $[111,112]$. 
Non-steroidal anti-inflammatory drugs (NSAIDs), acetaminophen, and prescription opioid medications are frequently prescribed for chronic pain [119]. Studies suggest that as many as $25 \%$ of patients with chronic liver disease receive opioid medications, [31,36,112]. Within the context of the dramatic increase in opioid prescribing in the last 10 to 15 years $[120,121]$ as well as common psychiatric and SUD co-morbidities found in patients with HCV, prescription opioid use greatly increases the risk of accidental or intentional overdose [122]. Opioid use in particular is known to increase with the progression of liver disease, which may reflect worsening pain or challenges in utilizing non-opioid pharmacological agents for pain management in this population [112].

There are special considerations when treating chronic pain in individuals with HCV. NSAIDs and acetaminophen can be detrimental for patients with severe liver disease particularly when used in high dosages [119]. As noted earlier, prescription opioids hold the risk for abuse and accidental or intentional overdose, particularly in those with a history of SUD and/or psychiatric illness [35, 119, 122]. Interferon-based therapies are known to significantly impair daily functioning and are associated with significant somatic symptoms, such as headache and various myalgias [123]. As such, patients with HCV and co-morbid pain diagnoses may be at risk for worsening symptoms and therefore more likely to use pain relieving medications that may alter or worsen their liver health. Careful consideration must be given when treating HCV patients with chronic pain and addressing the potential comorbidities or symptoms that may accompany antiviral treatment [123]. Greater emphasis must be placed on pharmacological and non-pharmacological treatments for pain in patients with $\mathrm{HCV}$ and comorbid chronic pain, including evidence-based psychotherapies that target pain, SUD, and depression [36, 111].

\section{The Presence of Multiple Comorbidities with HCV}

In addition to research pertaining to single comorbidities with $\mathrm{HCV}$, there is growing recognition of complexities related to $\mathrm{HCV}$ in people with two or more of the aforementioned conditions/diagnoses (i.e., depression, SUD, and pain). The proceeding sections will review relevant findings related to multiple comorbidities with HCV. Fig. (1) presents a conceptual model of interrelationships among depression, substance abuse and pain in people with HCV.

\section{HCV and Comorbid Depression and Substance Use Disorders}

The presence of both depression and SUD is often observed in patients with HCV [53]. Several studies, primarily retrospective chart reviews, have examined the prevalence of psychiatric and substance use disorder co-morbidities in Veterans with HCV infection. Medical record reviews of Veterans with HCV hospitalized in Veteran Health Administration (VHA) facilities between the years 1992 to 1999 showed that $86.4 \%$ had at least one psychiatric or substance use comorbidity and the vast majority of these had both [15]. A second retrospective chart review study reported that $89 \%$ of Veterans with liver disease attributable to HCV had documented psychiatric and/or SUD diagnoses [124].

Several studies have prospectively examined patients presenting for treatment in hepatology clinics. An initial study of current injection drug users with and without HCV found that $57.2 \%$ of patients with HCV had significant depressive symptoms as compared with $48.2 \%$ of the HCV-negative patients. This study found differences between groups in two specific dimensions of depression. Those subjects in the HCV-positive group scored lower on the "positive affect" dimension and higher on a "somatic/retarded activity" dimension. Also injection drug users with HCV had more severe depressive symptomatology [125]. Another study of patients with HCV who presented to a hepatology clinic found that 44.2\% had depression, 38.1\% had an anxiety disorder, 20.8\% had post-traumatic stress disorder (PTSD), 26.7\% had alcohol-related problems, and 37.2\% had two or more disorders [126]. Yet another study found that $93 \%$ of patients reporting to hepatology clinics for their initial assessment of $\mathrm{HCV}$ had an active or previous history of at least one psychiatric disorder and the majority had at least two disorders; depression was the most common disorder [6]. Also, $35 \%$ of Veterans had current BDI-II scores that suggested moderate-to-severe depression (i.e., a score greater than 18), and $21 \%$ had scores on the AUDIT-C that suggested current heavy alcohol use [6]. In summary multiple psychiatric (particularly depressive disorders) and substance use comorbidities are frequently present in people with HCV. 


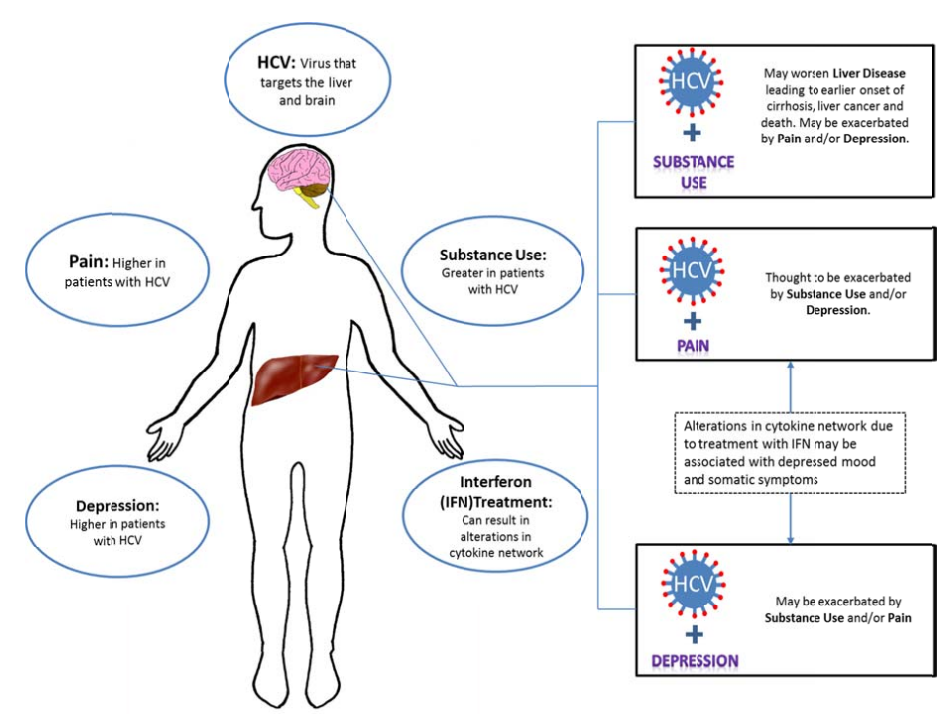

Fig 1. Interrelationships among depression, pain and substance use in patient with Hepatitis C.

\section{Somatic and Affective Depression in HCV}

Existing evidence suggests that HCV is distinctly associated with cognitive/affective and somatic symptoms of depression. A factor analysis of Beck Depression Inventory (BDI-II) scores in approximately 800 veterans with HCV suggested two primary symptom clusters: Cognitive-Affective and Somatic [9]. Items (or symptoms) for the CognitiveAffective cluster included pessimism, past-failure, guilty feelings, self-dislike and worthlessness; items for the Somatic cluster included loss of energy, appetite changes, concentration difficulty and fatigue. This study highlights the importance of recognizing depression as a multidimensional construct in HCV patients that can have physical and psychological manifestations.

The distinction between somatic and affective clusters of depressive symptomatology in patients with HCV is also important to understand within the context of antiviral treatment. A study of 32 treatment naïve Veterans found that treatment with IFN was associated with a significant increase in depressive symptoms when comparing pre-treatment depression scores to scores after 16 weeks of IFN exposure [127]. The most prominent increases in depressive symptoms included loss of appetite, fatigue and irritability (or neurovegetative and somatic symptoms), which were elevated during the first two weeks of IFN exposure and continued to increase through the 16 weeks of IFN treatment. These increases were predicted by high levels of Tumor Necrosis Factor - Alpha (TNF- $\alpha$ ) and low levels of serotonin levels prior to IFN exposure.

Another study examined this relationship in $764 \mathrm{HIV}$-infected patients, of these $160(21 \%)$ were co-infected with HCV [128]. The patients who were co-infected with HCV had an increase in depression severity and this difference remained after adjusting for substance use. However, HCV was no longer associated with depression when nondepression somatic symptoms were included in the multivariate analysis as covariates [128]. Overall these findings indicate a strong relationship between symptom burden and depression, as somatic symptoms (independent of depression) may indirectly contribute to the presence and severity of depression in this co-infected population.

Among somatic symptoms of depression, fatigue is common in HCV and some studies suggest that it too may relate to co-morbid psychiatric illness rather than to hepatic disease severity secondary to HCV infection. One study found that of a sample of HCV patients $40 \%$ were currently depressed, $70 \%$ had lifetime depression/dysthymia, 56\% had lifetime histories of problematic alcohol use, and $46 \%$ had lifetime histories of illicit drug use [5]. In this study depression was not associated with liver disease severity (as determined by the Knodell Score and fibrosis stage) but was associated with somatic symptoms and interference from fatigue. These findings indicate that fatigue and disability may be more closely related to the severity of depression than to the severity of hepatic disease.

\section{Effect of Pain in Veterans with HCV and SUD}

Patients with HCV and comorbid SUD have been reported to have significantly higher rates of diagnoses related to 
pain than patients with HCV who do not have a comorbid SUD [32]. Also the use of social supports as coping mechanism for chronic pain and pain catastrophizing were found to be associated with the severity of pain [36].The relationship between pain and substance use in individuals with HCV is important to consider, particularly within the context of pharmacological pain management.

Studies have demonstrated an association between opioid use and psychological variables in HCV patients with pain. One chronic liver disease study found that among 1,286 participants, $34 \%$ had pain and $25 \%$ were prescribed opioid medications [112]. Furthermore of people with pain more than 50\% rated their pain as moderate to severe. Emotional distress was the strongest predictor of pain followed by non-white race, symptoms suggestive of a mood disorder, sleep disturbance or fatigue, and advanced liver disease. Predictors of prescription opioid use included advanced liver disease as well as etiology of liver disease, emotional distress, symptoms suggestive of a mood disorder, nicotine use and age. The high prevalence of pain and opioid use in people who have chronic liver disease is evident in this study. Furthermore psychological factors were most strongly associated with pain and opioid use and suggest that therapeutic interventions should target these factors.

In a retrospective medical record review study of 8,224 Veterans with HCV, $29 \%$ had been prescribed an opioid medication in the past year and $46 \%$ had been prescribed an opioid medication in the last 3 years [32]. Sixty-seven percent of these Veterans had documented pain-related diagnoses and over half had a SUD. Veterans who had both pain and a SUD were less likely to receive opioid medications than Veterans who only had a pain-related diagnosis. Of interest Veterans with co-occurring pain and a SUD were no more likely to get an early opioid medication prescription refill than Veterans with a pain-related diagnosis and no comorbid SUD. Specific to Veterans who had a pain-related diagnosis and an opioid use disorder, they had fewer early opioid fills than Veterans who had only a pain-related diagnosis [32].

Overall these findings suggest that people with HCV are also very likely to have comorbid pain-related diagnoses and one or more SUDs, and receive prescriptions for opioids. However, there is no evidence to suggest that people who have HCV and comorbid SUD are misusing prescribed opioids. This last point has particular implications for antiviral treatment.

\section{DISCUSSION}

The present review highlights the importance of understanding the complexities that can arise when HCV is accompanied by depression, SUD, and/or chronic pain. Overall, studies suggest that psychiatric disorders as well as substance use disorders are highly prevalent in people with HCV and are associated with adverse experiences of illness and lower quality of life. Furthermore psychosocial variables, such as depression, can significantly exacerbate the severity of pain as well as and pain functioning in this population. Both pain and depression independently increase the likelihood of high risk behaviors such as excessive alcohol and substance use, which in return can dramatically accelerate the progression of liver disease caused by HCV.

Psychiatric, substance use, and pain disorders may occur and co-occur independent of HCV infection. However, the co-occurrence of one or more of these conditions is significantly more likely in patients with HCV and provides an opportunity to examine the common underlying biological mechanisms shared among these co-morbidities. The cooccurrence of these disorders significantly impairs quality of life and daily functioning in this particular population and may also adversely affect eligibility for antiviral treatment.

Understanding the intersection of biological and psychosocial factors that adversely impact patients with HCV is critical and has important implications for the trajectory of infection and treatment. Rather than existing in isolation, chronic HCV and its comorbidities likely interact with each other in a manner that can significantly affect the severity and course of illness and the patient's subjective experience of it. For example, substance abuse can not only result in transmission of HCV but introduces challenges with regard to modifying patient behavior to engage in and adhere to antiviral treatment. As noted earlier, an increase in pro-inflammatory cytokines, particularly during treatment with IFNbased therapies, can be associated with depressive symptoms and pain. In turn, these symptoms can exacerbate previous substance use as a means of self-medication. Furthermore, aggravation of depressive symptoms and pain may complicate factors that are critical to management of $\mathrm{HCV}$, such as antiviral treatment adherence. Accounting for this interplay of variables allows conceptualization of $\mathrm{HCV}$ as a biopsychosocial phenomenon rather than a medical condition alone. 


\section{Implications For Assessment and Treatment}

Multiple comorbidities found among patients with HCV underscores the necessity for care that can meet the multifaceted needs of these patients. Providers who can address both medical and mental health concerns are instrumental in providing optimal care for patients with HCV. As such, an interdisciplinary team approach may best meet the needs of patients with HCV. Interdisciplinary teams that can provide both medical and social support to the patient will increase the likelihood of completion of antiviral treatment $[129,130]$. This integrated model of care makes it more likely that depression and other psychiatric side effects will be identified during the course of antiviral treatment and allow people who have pre-existing psychiatric illness (even if a serious mental illness) to initiate and complete treatment for HCV [131].

Furthermore, routine screening for AUDs and SUDs is imperative prior to the start antiviral therapy. Studies suggest that individuals who are abstinent six months prior to treatment have better outcomes and are more likely to obtain SVR. Although abstinence among mild to moderate drinkers is not required, all levels of alcohol consumption should be assessed prior to- and carefully monitored throughout the duration of-antiviral treatment. History of SUD should not be exclusionary for treatment, but need to be proactively assessed and managed.

Studies suggest that drug abuse treatment centers that deliver both medical and psychosocial services result in higher patient utilization of these services, better compliance with medications that are prescribed and better medical outcomes [91]. Detecting HCV infection in the structured setting of SUD treatment clinics is optimal for early HCV diagnosis and antiviral treatment and has a positive influence on the outcomes of both substance abuse treatment and HCV treatment [96]. Routine screening and early interventions for psychiatric disorders and substance use disorders increases likelihood of early detection and treatment as well as better antiviral outcomes.

As mentioned, substance use and depressive symptoms may negatively impact coexisting pain diagnoses. Studies indicate that routine screening and treatment of psychiatric disorders (particularly depression) can lead to better pain management in people who have a chronic liver disease, which, may improve quality of life and treatment outcomes [132]. Furthermore, physicians who are aware of the wide range of musculoskeletal complaints that may co-occur with $\mathrm{HCV}$, such as head, back and neck pain, and fibromyalgia syndrome, are in a better position to provide appropriate health care $[113,118]$. It is recommended that people who have HCV and chronic pain are thoroughly assessed for psychosocial factors including depression severity, current use of alcohol or other substances as well as problems specifically associated with pain [36].

Table 2. Studies of IFN-induced depression.

\begin{tabular}{|c|c|c|c|c|}
\hline References & $\begin{array}{l}\text { Sample Size and } \\
\text { Characteristics }\end{array}$ & Purpose and Design & $\begin{array}{l}\text { Rating Scales for } \\
\text { Depression }^{1}\end{array}$ & Outcome \\
\hline $\begin{array}{l}\text { Otsubo et al. } \\
{[134]}\end{array}$ & $\begin{array}{l}85 \text { patients with } \mathrm{HCV} \\
\text { receiving IFN therapy at a } \\
\text { university hospital }\end{array}$ & $\begin{array}{l}\text { Prospective assessment ( } 6 \text { month } \\
\text { treatment period) of depression } \\
\text { during IFN therapy }\end{array}$ & $\begin{array}{l}\text { Diagnostic and } \\
\text { Statistical Manual for } \\
\text { Mental Disorders -III } \\
\text { Revised (DSM-IIIR), } \\
\text { Hamilton Depression } \\
\text { Rating Scale (HAM-D) } \\
\end{array}$ & $\begin{array}{l}37.3 \% \text { of individuals who were } \\
\text { asymptomatic for depression at the start } \\
\text { of treatment were diagnosed with MDD } \\
\text { at least once during IFN treatment. }\end{array}$ \\
\hline $\begin{array}{l}\text { Hosoda et al. } \\
{[135]}\end{array}$ & $\begin{array}{l}943 \text { patients with HCV } \\
\text { treated with IFN therapy }\end{array}$ & Retrospective chart review & $\begin{array}{l}\text { Chart diagnoses in } \\
\text { medical record }\end{array}$ & $\begin{array}{l}\text { Approximately } 4.2 \% \text { of patients } \\
\text { manifested psychiatric symptoms during } \\
\text { the course of treatment. } 2.2 \% \text { were } \\
\text { diagnosed with a mood disorder with } \\
\text { depressive features. }\end{array}$ \\
\hline $\begin{array}{l}\text { Mulder et al. } \\
{[136]}\end{array}$ & $\begin{array}{l}63 \text { patients with } \mathrm{HCV} \\
\text { treated with IFN in a } \\
\text { hospital Hepatology clinic }\end{array}$ & $\begin{array}{l}\text { Prospectively assessed (6 month } \\
\text { treatment period) psychiatric } \\
\text { symptoms, including depression } \\
\text { during IFN treatment }\end{array}$ & $\begin{array}{l}\text { SCID; Hopkins } \\
\text { Symptom Checklist-90 } \\
\text { (SCL-90) }\end{array}$ & $\begin{array}{l}\text { No increase in depressive symptoms was } \\
\text { observed. }\end{array}$ \\
\hline $\begin{array}{l}\text { Hauser et al. } \\
{[11]}\end{array}$ & $\begin{array}{l}39 \text { patients with HCV } \\
\text { treated with IFN therapy at } \\
\text { a VA Hospital }\end{array}$ & $\begin{array}{l}\text { Prospective Cohort study ( } 6 \text { to } 12 \\
\text { month treatment period) to } \\
\text { determine the incidence of IFN- } \\
\text { induced MDD and the efficacy of } \\
\text { open-label SSRIs to treat IFN- } \\
\text { induced MDD }\end{array}$ & $\begin{array}{l}\text { BDI family history of } \\
\text { MDD, past history of } \\
\text { MDD }\end{array}$ & $\begin{array}{l}\text { A past history of MDD or SUD was not } \\
\text { associated with an increased risk of IFN- } \\
\text { induced MDD. However, patients who } \\
\text { later met criteria for IFN-induced MDD } \\
\text { had baseline BDI scores that were } \\
\text { significantly higher than patients who did } \\
\text { not develop IFN-induced MDD. }\end{array}$ \\
\hline
\end{tabular}




\begin{tabular}{|c|c|c|c|c|}
\hline References & $\begin{array}{l}\text { Sample Size and } \\
\text { Characteristics }\end{array}$ & Purpose and Design & $\begin{array}{l}\text { Rating Scales for } \\
\text { Depression }^{1}\end{array}$ & Outcome \\
\hline $\begin{array}{l}\text { Dieperink et al. } \\
\text { [57] }\end{array}$ & $\begin{array}{l}55 \text { patients with HCV } \\
\text { treated with IFN therapy at } \\
\text { a VA Hospital }\end{array}$ & $\begin{array}{l}\text { Prospective assessment ( } 24 \text { week } \\
\text { treatment period) of } \\
\text { neuropsychiatric symptoms in } \\
\text { patients receiving IFN-based } \\
\text { antiviral therapy }\end{array}$ & $\begin{array}{l}\text { HAM-D, BDI, ZRDS, } \\
\text { Positive and Negative } \\
\text { Affect Scale (PANAS), } \\
\text { POMS, SF-36 }\end{array}$ & $\begin{array}{l}23 \% \text { of Patients not in psychiatric care at } \\
\text { baseline, developed symptoms consistent } \\
\text { with MDD and } 48 \% \text { required treatment } \\
\text { for neuropsychiatric side effects. }\end{array}$ \\
\hline $\begin{array}{l}\text { Gohier et al. } \\
{[137]}\end{array}$ & $\begin{array}{l}71 \mathrm{HCV} \text { patients treated } \\
\text { with IFN therapy }\end{array}$ & $\begin{array}{l}\text { Prospective study (1 year } \\
\text { treatment period) of depressive } \\
\text { and anxiety symptoms during IFN- } \\
\text { based antiviral therapy }\end{array}$ & $\begin{array}{l}\text { Montgomery Asberg } \\
\text { Depression Rating Scale } \\
\text { (MADRS) }\end{array}$ & $\begin{array}{l}\text { Risk of developing depression, suicidal } \\
\text { ideation, or anxiety during treatment was } \\
33 \% \text {. Risk of developing depression } \\
\text { specifically was } 23 \% \text {. }\end{array}$ \\
\hline $\begin{array}{l}\text { Horikawa et al. } \\
{[138]}\end{array}$ & $\begin{array}{l}99 \text { HCV patients treated } \\
\text { with IFN therapy in a } \\
\text { hospital setting }\end{array}$ & $\begin{array}{l}\text { Prospective study ( } 24 \text { week } \\
\text { treatment period) of MDD during } \\
\text { IFN- based antiviral therapy }\end{array}$ & HAM-D & $\begin{array}{l}\text { Approximately } 23 \% \text { of patients } \\
\text { developed IFN-induced MDD; however } \\
59.1 \% \text { of depressed patients achieved } \\
\text { remission by the end of treatment. }\end{array}$ \\
\hline $\begin{array}{l}\text { Raison et al. } \\
\text { [139] }\end{array}$ & $\begin{array}{l}102 \text { patients with } \\
\text { HCVtreated with IFN } \\
\text { therapy as part of a } \\
\text { multicenter clinical trial }\end{array}$ & $\begin{array}{l}\text { Prospective cohort study ( } 3 \text { years) } \\
\text { of association between depression } \\
\text { and viral clearance during } \\
\text { treatment with IFN- based antiviral } \\
\text { therapy. }\end{array}$ & ZRDS & $\begin{array}{l}\text { Individuals with increased depression } \\
\text { during IFN/ribavirin therapy may be less } \\
\text { likely to experience viral clearance. }\end{array}$ \\
\hline $\begin{array}{l}\text { Reichenberg et } \\
\text { al. }[140]\end{array}$ & $\begin{array}{l}50 \text { patients with } \mathrm{HCV} \\
\text { being treated with IFN } \\
\text { therapy }\end{array}$ & $\begin{array}{l}\text { Prospective study ( } 72 \text { week } \\
\text { treatment and follow up period) of } \\
\text { depression and cognitive } \\
\text { impairment during and after IFN- } \\
\text { based treatment. }\end{array}$ & \begin{tabular}{|l|} 
Center for \\
Epidemiological Studies \\
Depression (CES-D) \\
Questionnaire
\end{tabular} & $\begin{array}{l}82 \% \text { developed depressive symptoms } \\
\text { indicative of possible MDD. Higher } \\
\text { baseline (pre-IFN treatment) depression } \\
\text { scores associated with greater severity of } \\
\text { IFN-induced depressive symptoms }\end{array}$ \\
\hline Dan et al. [141] & $\begin{array}{l}271 \text { patients with } \mathrm{HCV} \\
\text { being treated with IFN } \\
\text { therapy }\end{array}$ & $\begin{array}{l}\text { Prospective study ( } 72 \text { week } \\
\text { treatment and follow up period) of } \\
\text { the association between HRQOL } \\
\text { score and } \\
\text { IFN- induced depression/ anemia. }\end{array}$ & CES-D & $\begin{array}{l}\text { Depression was a predictor of lower } \\
\text { HRQOL. IFN therapy was not associated } \\
\text { with reduced HRQOL by the end of } \\
\text { treatment. }\end{array}$ \\
\hline $\begin{array}{l}\text { Hauser et al. } \\
{[74]}\end{array}$ & $\begin{array}{l}55 \text { patients with HCV with } \\
\text { and without MDD from a } \\
\text { single VA medical center }\end{array}$ & $\begin{array}{l}\text { Retrospective chart review to } \\
\text { compare completion and SVR } \\
\text { rates }\end{array}$ & $\begin{array}{l}\text { Chart diagnoses in } \\
\text { medical records. }\end{array}$ & $\begin{array}{l}\text { Patients with and without MDD had } \\
\text { similar completion and SVR rates. } \\
\text { Patients with MDD can be safely and } \\
\text { effectively treated with antiviral therapy. }\end{array}$ \\
\hline
\end{tabular}

${ }^{1}$ Refer to Appendix A for list of measures associated with abbreviations. Notes:

-Original studies with $>15$ subjects with $\mathrm{HCV}$ were included in table.

-Studies with non-human subjects omitted.

-Literature Review studies omitted.

- Studies that did not use a depression rating scale were omitted.

It is also critical to note the implications of utilizing newer antiviral drugs in the context of HCV and common comorbidities. The development of new medications, including direct acting antiviral agents (DAA) that are used to treat HCV has allowed providers to treat people who have or are at risk for pain, depression, and SUD and otherwise would have been excluded from antiviral treatment [133]. Telaprevir, simeprevir and sofosbuvir in combination with IFN therapy can significantly decrease treatment duration without exacerbating side effects of interferon therapy, such as depressive symptomatology and muscle aches. Ultimately, some patients have been successfully treated in as little as 12 weeks of combination therapy, the time frame after which many of these side effects typically develop.

Table 3. Biological associations and risk factors for IFN-induced depression.

\begin{tabular}{|l|l|l|l|l|}
\hline References & $\begin{array}{l}\text { Sample Size and } \\
\text { Characteristics }\end{array}$ & Purpose and Design & $\begin{array}{l}\text { Rating Scales for } \\
\text { Depression }\end{array}$ & Outcome \\
\hline $\begin{array}{l}\text { Bonaccorso et } \\
\text { al. }[60]\end{array}$ & $\begin{array}{l}\text { 18 patients with HCV treated } \\
\text { with IFN in a university medical } \\
\text { clinic }\end{array}$ & $\begin{array}{l}\text { Prospective study (7 months) of } \\
\text { serotonin and its precursors in blood } \\
\text { during IFN treatment }\end{array}$ & MADRS & $\begin{array}{l}\text { An increase in depression observed, as } \\
\text { well as a decrease in serum 5-HT } \\
\text { levels. }\end{array}$ \\
\hline $\begin{array}{l}\text { Loftis } \text { et al. } \\
\text { [54] }\end{array}$ & $\begin{array}{l}33 \text { HCV patients treated with } \\
\text { IFN therapy in a VA hospital } \\
\text { setting }\end{array}$ & $\begin{array}{l}\text { Prospective assessment of impact of } \\
\text { IFN- based antiviral therapy on } \\
\text { thyroid function and depression }\end{array}$ & $\begin{array}{l}\text { Diagnostic and } \\
\text { Statistical Manual } \\
\text { for Mental } \\
\text { Disorders - IV } \\
\text { (DSM IV), BDI }\end{array}$ & $\begin{array}{l}\text { Depressive symptoms were associated } \\
\text { with IFN therapy, however there was no } \\
\text { observed associations between IFN- } \\
\text { induced depression and changes in } \\
\text { thyroid function }\end{array}$ \\
\hline
\end{tabular}




\begin{tabular}{|c|c|c|c|c|}
\hline References & $\begin{array}{l}\text { Sample Size and } \\
\text { Characteristics }\end{array}$ & Purpose and Design & $\begin{array}{l}\text { Rating Scales for } \\
\text { Depression }^{1}\end{array}$ & Outcome \\
\hline $\begin{array}{l}\text { Yoshida et al. } \\
\text { [142] }\end{array}$ & $\begin{array}{l}50 \text { patients with HCV selected } \\
\text { from larger sample of HCV } \\
\text { patients from south eastern US. }\end{array}$ & $\begin{array}{l}\text { Assessment to determine if promoter } \\
\text { polymorphisms of interferon- } \alpha \\
\text { receptor gene is associated with IFN- } \\
\text { induced depression over } 24 \text { weeks of } \\
\text { treatment }\end{array}$ & ZRDS & $\begin{array}{l}\text { Promoter GT repeat dinucleotide } \\
\text { microsatellite } \\
\text { polymorphism of the IFNAR1 gene } \\
\text { could serve as a risk factor for } \\
\text { developing depression during treatment } \\
\text { with interferon }\end{array}$ \\
\hline $\begin{array}{l}\text { Wichers et al. } \\
\text { [143] }\end{array}$ & $\begin{array}{l}16 \text { patients with HCV without } \\
\text { psychiatric disorders treated with } \\
\text { IFN therapy from a University } \\
\text { Medical center }\end{array}$ & $\begin{array}{l}\text { Prospective assessment ( } 24 \text { week } \\
\text { treatment period) of immune } \\
\text { activation/ cytokine blood levels and } \\
\text { associated depression during IFN } \\
\text { therapy }\end{array}$ & MADRS & $\begin{array}{l}\text { Findings identified causal relationship } \\
\text { between baseline levels of certain } \\
\text { cytokines and development of MDD } \\
\text { during IFN therapy }\end{array}$ \\
\hline Kraus [144] & $\begin{array}{l}139 \text { patients with } \mathrm{HCV} \text { treated } \\
\text { with IFN therapy at a University } \\
\text { Clinic }\end{array}$ & $\begin{array}{l}\text { Prospective assessment (6 years) of } \\
\text { functional gene variants of 5-HT and } \\
\text { depression during IFN-based } \\
\text { antiviral therapy }\end{array}$ & $\begin{array}{l}\text { Hospital Anxiety } \\
\text { and Depression } \\
\text { Scale (HADS) }\end{array}$ & $\begin{array}{l}\text { Allelic variation in 5-HT1A receptor } \\
\text { was associated with IFN induced } \\
\text { depression }\end{array}$ \\
\hline $\begin{array}{l}\text { Loftis et al. } \\
{[61]}\end{array}$ & $\begin{array}{l}23 \text { patients with and without } \\
\text { HCV ( } 16 \text { with HCV and } 7 \\
\text { without } \mathrm{HCV}) \text { from a single VA } \\
\text { hospital }\end{array}$ & $\begin{array}{l}\text { Prospective evaluation of depression } \\
\text { and cytokine levels in HCV }\end{array}$ & BDI & $\begin{array}{l}\text { Results show an association between } \\
\text { severity of depressive symptoms and } \\
\text { expression of proinflammatory } \\
\text { cytokines in patients with HCV }\end{array}$ \\
\hline
\end{tabular}

${ }^{1}$ Refer to Appendix A for list of measures associated with abbreviations.

Notes

-Original studies with $>15$ subjects were included in table.

-Studies with non-human subjects omitted.

-Literature Review studies were omitted.

Table 4. Treatment and prevention of IFN-induced depression.

\begin{tabular}{|c|c|c|c|c|}
\hline References & $\begin{array}{l}\text { Sample Size and } \\
\text { Characteristics }\end{array}$ & Purpose and Design & $\begin{array}{l}\text { Rating Scales for } \\
\text { Depression }^{1}\end{array}$ & Outcome \\
\hline $\begin{array}{l}\text { Gleason et al. } \\
{[69]}\end{array}$ & $\begin{array}{l}15 \text { patients with HCV from } \\
\text { an urban community }\end{array}$ & \begin{tabular}{|l|} 
Open label clinical trial to \\
assess the efficacy of citalopram \\
to reduce symptoms of \\
depression
\end{tabular} & $\begin{array}{l}\text { HAM-D, Clinical Global } \\
\text { Impressions-Severity of } \\
\text { Illness Scale (CGI-S), } \\
\text { SF-36, SCL-90 }\end{array}$ & $\begin{array}{l}\text { Depression in patients with hepatitis C } \\
\text { may be effectively and safely treated } \\
\text { with citalopram. }\end{array}$ \\
\hline $\begin{array}{l}\text { Laguno et al. } \\
{[145]}\end{array}$ & $\begin{array}{l}113 \text { patients co-infected with } \\
\text { HIV/HCV treated with IFN } \\
\text { therapy }\end{array}$ & $\begin{array}{l}\text { Prospective assessment ( } 2 \\
\text { years) of treatment during IFN- } \\
\text { based antiviral therapy }\end{array}$ & $\begin{array}{l}\text { International classification } \\
\text { of Diseases, } 10^{\text {th }} \text { Revision } \\
\text { (ICD-10) }\end{array}$ & $\begin{array}{l}40 \% \text { of participants developed } \\
\text { depressive symptoms - of these } 44 \% \\
\text { were treated with citalopram and } \\
\text { demonstrated depressive symptom } \\
\text { improvement }\end{array}$ \\
\hline $\begin{array}{l}\text { Kraus et al. } \\
{[71]}\end{array}$ & $\begin{array}{l}17 \text { patients with } \mathrm{HCV} \text { being } \\
\text { retreated with IFN therapy }\end{array}$ & $\begin{array}{l}\text { Prospective study (4 years) of } \\
\text { prophylactic SSRIs in patients } \\
\text { who experienced IFN-induced } \\
\text { depression during previous } \\
\text { treatment }\end{array}$ & HADS & $\begin{array}{l}\text { Prophylactic SSRI use reduced } \\
\text { likelihood of IFN-induced depression. }\end{array}$ \\
\hline $\begin{array}{l}\text { Schaefer et al. } \\
{[67]}\end{array}$ & $\begin{array}{l}14 \text { patients with HCV and } \\
\text { psychiatric disorders } \\
\text { receiving citalopram and } 22 \\
\text { patients with HCV with and } \\
\text { without psychiatric disorders } \\
\text { not receiving antidepressant } \\
\text { therapy }\end{array}$ & $\begin{array}{l}\text { Prospective assessment of the } \\
\text { efficacy of antidepressant } \\
\text { prophylaxis using citalopram. }\end{array}$ & $\begin{array}{l}\text { Psychiatric interview, } \\
\text { DSM-IV diagnostic criteria. }\end{array}$ & $\begin{array}{l}\text { Pre-treatment of psychiatric patients } \\
\text { with citalopram significantly reduced } \\
\text { the incidence of major depression } \\
\text { during the first } 6 \text { months of antiviral } \\
\text { treatment as compared to the two } \\
\text { control groups. } \\
\text { Patients who developed symptoms of } \\
\text { major } \\
\text { depression during IFN therapy could } \\
\text { also be improved by anti-depressive } \\
\text { treatment. }\end{array}$ \\
\hline $\begin{array}{l}\text { Morasco et al. } \\
{[75]}\end{array}$ & $\begin{array}{l}33 \text { patients with } \mathrm{HCV} \\
\text { recruited from multiple VA } \\
\text { hospitals }\end{array}$ & $\begin{array}{l}\text { Randomized double blind } \\
\text { placebo controlled trial } \\
\text { assessing efficacy of paroxetine } \\
\text { in preventing IFN-induced } \\
\text { depression }\end{array}$ & SCID, HAM-D & $\begin{array}{l}\text { Depression developed in an average of } \\
33.3 \% \text { of patients }(35.7 \% \text { in the } \\
\text { paroxetine group vs. } 31.6 \% \text { in the } \\
\text { placebo group) -label treatment with } \\
\text { paroxetine helped reduce depressive } \\
\text { symptoms when implemented after the } \\
\text { initiation of antiviral treatment }\end{array}$ \\
\hline
\end{tabular}




\begin{tabular}{|l|l|l|l|l|}
\hline (Table 4) contd..... & $\begin{array}{l}\text { Peferences } \\
\text { Characteristics }\end{array}$ & $\begin{array}{l}\text { Pating Scales for } \\
\text { Depression }\end{array}$ & Outcome \\
\hline $\begin{array}{l}\text { Morasco } \text { et al. } \\
{[81]}\end{array}$ & $\begin{array}{l}39 \text { patients with HCV } \\
\text { recruited from two VA } \\
\text { hospitals }\end{array}$ & $\begin{array}{l}\text { Randomized controlled trial } \\
\text { examining the efficacy of } \\
\text { citalopram to prevent IFN } \\
\text { induced depression }\end{array}$ & SCID, BDI, MADRS & $\begin{array}{l}\text { Citalopram did not prevent the onset of } \\
\text { IFN-induced depression; } \\
\text { neuropsychiatric side effects should be } \\
\text { well monitored during treatment with } \\
\text { IFN. }\end{array}$ \\
\hline $\begin{array}{l}\text { Kraus } \text { et al. } \\
{[72]}\end{array}$ & $\begin{array}{l}100 \text { outpatients with HCV } \\
\text { from a University Liver } \\
\text { Clinic }\end{array}$ & $\begin{array}{l}\text { Randomized, double blind, } \\
\text { placebo controlled study to } \\
\text { assess the efficacy of SSRIs to } \\
\text { treat IFN induced depression }\end{array}$ & HADS & $\begin{array}{l}\text { Citalopram treatment is highly effective } \\
\text { in HCV patients on } \\
\text { IFN therapy, when initiated after the } \\
\text { onset of clinically } \\
\text { relevant depressive symptoms. }\end{array}$ \\
\hline
\end{tabular}

${ }^{1}$ Refer to Appendix A for list of measures associated with abbreviations.

Notes

-Original studies with $>15$ subjects were included in table.

-Studies with non-human subjects omitted.

-Literature Review studies were omitted.

Table 5. Alcohol use and disease progression in HCV.

\begin{tabular}{|c|c|c|c|c|}
\hline References & $\begin{array}{l}\text { Sample Size and } \\
\text { characteristics }\end{array}$ & Purpose of study & $\begin{array}{l}\text { Rating Scales for } \\
\text { Alcohol Use }\end{array}$ & Outcome \\
\hline Kubo et al. [84] & $\begin{array}{l}122 \text { patients with HCV and } \\
\text { hepatocellular carcinoma } \\
\text { (HCC) from a university } \\
\text { hospital }\end{array}$ & $\begin{array}{l}\text { Prospective assessment (4 years) } \\
\text { of alcohol use and the } \\
\text { development of (HCC) }\end{array}$ & $\begin{array}{l}\text { Daily alcohol intake } \\
\geq 86 \mathrm{~g} / \text { day or }<86 \mathrm{~g} / \text { day } \\
\text { in the past } 5 \text { years. }\end{array}$ & $\begin{array}{l}\text { Alcohol use increases the risk for } \\
\text { HCC. }\end{array}$ \\
\hline Serfaty et al. [85] & $\begin{array}{l}168 \text { patients with } \mathrm{HCV} \text { with } \\
\text { and without cirrhosis from a } \\
\text { hospital Hepatology clinic }\end{array}$ & $\begin{array}{l}\text { Case-control study (4 years) } \\
\text { assessing } \\
\text { alcohol consumption and liver } \\
\text { damage }\end{array}$ & $\begin{array}{l}\text { Daily alcohol intake } \\
>80 \mathrm{~g} / \text { day, } 30-80 \mathrm{~g} / \text { day, } \\
<30 \mathrm{~g} / \text { day over } 10 \text { year } \\
\text { periods }\end{array}$ & $\begin{array}{l}\text { Alcohol consumption, even in } \\
\text { moderate amounts, is a risk factor for } \\
\text { cirrhosis independent of genotype, } \\
\text { phenotype and history of HBV. }\end{array}$ \\
\hline $\begin{array}{l}\text { Roudot-Thoraval et } \\
\text { al. [83] }\end{array}$ & $\begin{array}{l}6664 \text { patients with } \mathrm{HCV} \\
\text { from a hospital clinic }\end{array}$ & $\begin{array}{l}\text { Prospective assessment ( } 3 \text { years) } \\
\text { of epidemiological factors } \\
\text { affecting the severity of liver } \\
\text { disease in patients with HCV. }\end{array}$ & $\begin{array}{l}\text { Chart diagnoses, } \\
\text { demographic data and } \\
\text { alcohol use listed in } \\
\text { medical records }\end{array}$ & $\begin{array}{l}\text { Excessive alcohol intake was } \\
\text { associated with a higher risk of } \\
\text { cirrhosis in patients with HCV. }\end{array}$ \\
\hline $\begin{array}{l}\text { Corrao and Arico } \\
{[17]}\end{array}$ & $\begin{array}{l}702 \text { cirrhotic patients with } \\
\text { and without liver } \\
\text { decompensation from } \\
\text { alcohol use from a hospital } \\
\text { clinic }\end{array}$ & $\begin{array}{l}\text { Prospective assessment (4 years) } \\
\text { of the effect of alcohol intake and } \\
\mathrm{HCV} \text { on development of liver } \\
\text { cirrhosis. }\end{array}$ & $\begin{array}{l}\text { Lifetime Daily } \\
\text { Alcohol Intake (LDAI) }\end{array}$ & $\begin{array}{l}\text { In subjects with high alcohol intake, } \\
\text { the coexistence } \\
\text { of HCV infection increases the } \\
\text { alcohol-associated risk of cirrhosis. }\end{array}$ \\
\hline Wiley et al. [86] & $\begin{array}{l}44 \text { Patients with HCV and } \\
\text { history of moderate to } \\
\text { excessive use of alcohol } \\
\text { from a Hepatology clinic at a } \\
\text { University Hospital }\end{array}$ & $\begin{array}{l}\text { Retrospective Chart review } \\
\text { examining the effect of moderate } \\
\text { alcohol intake on HCV } \\
\text { progression }\end{array}$ & $\begin{array}{l}\text { Daily Alcohol Intake } \\
>40 \mathrm{~g} \text { for women and } \\
>60 \mathrm{~g} \text { for men }\end{array}$ & $\begin{array}{l}\text { There is a two to } \\
\text { threefold increased risk of liver } \\
\text { cirrhosis and decompensated } \\
\text { liver disease in patients who consume } \\
\text { moderate amounts of alcohol as well } \\
\text { as more rapid progression to cirrhosis. }\end{array}$ \\
\hline $\begin{array}{l}\text { Ostapowics et al. } \\
{[18]}\end{array}$ & $\begin{array}{l}234 \text { patients with HCV from } \\
\text { a hospital Hepatology clinic }\end{array}$ & $\begin{array}{l}\text { Retrospective Cohort study } \\
\text { assessing the effects of lifetime } \\
\text { alcohol consumption }\end{array}$ & LDAI & $\begin{array}{l}\text { Total lifetime alcohol } \\
\text { consumption is a risk factor for the } \\
\text { progression of liver } \\
\text { disease caused by HCV. }\end{array}$ \\
\hline Khan et al. [19] & $\begin{array}{l}120 \text { patients with HCV and a } \\
\text { history of light, moderate, } \\
\text { heavy or excessive alcohol } \\
\text { consumption recruited from } \\
\text { a hospital Hepatology clinic }\end{array}$ & $\begin{array}{l}\text { Prospective single assessment of } \\
\text { moderate and heavy drinking and } \\
\text { risk for HCC. }\end{array}$ & $\begin{array}{l}\text { Chart diagnoses in } \\
\text { medical records, } \\
\text { clinical interviews. } \\
\text { Moderate drinking as } \\
<80 \mathrm{~g} / \text { day } \\
\text { Heavy drinking as } \\
>80 \mathrm{~g} / \text { day }\end{array}$ & $\begin{array}{l}\text { Increased risk of cirrhosis and HCC in } \\
\text { patients with HCV consuming } \\
\text { moderate and high amounts of } \\
\text { alcohol. Alcohol consumption is also } \\
\text { associated with greater risk for gastro- } \\
\text { esophageal variceal bleeding, ascites } \\
\text { and hepatic encephalopathy. }\end{array}$ \\
\hline Harris et al. [87] & $\begin{array}{l}1030 \text { patients with HCV } \\
\text { from Hepatology clinics in } \\
\text { University and Government } \\
\text { Hospitals }\end{array}$ & $\begin{array}{l}\text { Retrospective chart review to } \\
\text { quantify the relationship of } \\
\text { transfusion-associated } \\
\text { HCV infection and history of } \\
\text { heavy alcohol use }\end{array}$ & $\begin{array}{l}\text { Clinical interviews, } \\
\text { chart diagnoses in } \\
\text { medical records }\end{array}$ & $\begin{array}{l}\text { Heavy alcohol abuse greatly } \\
\text { exacerbates the risk for cirrhosis } \\
\text { among patients with HCV infection. }\end{array}$ \\
\hline
\end{tabular}




\begin{tabular}{|c|c|c|c|c|}
\hline References & $\begin{array}{l}\text { Sample Size and } \\
\text { characteristics }\end{array}$ & Purpose of study & $\begin{array}{l}\text { Rating Scales for } \\
\text { Alcohol Use }^{1}\end{array}$ & Outcome \\
\hline Westin et al. [88] & $\begin{array}{l}78 \text { patients with } \mathrm{HCV} \\
\text { infection and moderate } \\
\text { alcohol consumption from a } \\
\text { University Hospital }\end{array}$ & $\begin{array}{l}\text { Retrospective cohort study } \\
\text { evaluating the effect of moderate } \\
\text { alcohol consumption } \\
\text { on fibrosis progression. }\end{array}$ & $\begin{array}{l}\text { Lifetime drinking } \\
\text { history and LDAI }\end{array}$ & $\begin{array}{l}\text { Alcohol intake/ consumption are } \\
\text { associated with more rapid } \\
\text { progression to liver fibrosis in patients } \\
\text { with HCV. Even moderate alcohol } \\
\text { consumption increases rate of } \\
\text { progression, suggesting total } \\
\text { abstinence most beneficial. }\end{array}$ \\
\hline Donato et al. [21] & \begin{tabular}{|l|}
1248 patients with and \\
without HCV, HBV and \\
HCC and a history of alcohol \\
use hospitalized between \\
1995 and $2000(218$ with \\
HCV)
\end{tabular} & $\begin{array}{l}\text { Prospective Cohort Study ( } 5 \\
\text { years) assessing alcohol use and } \\
\text { HCC in current and former } \\
\text { drinkers }\end{array}$ & $\begin{array}{l}\text { Self-report history of } \\
\text { alcohol use, measured } \\
\text { by ethanol content and } \\
\text { volume }\end{array}$ & $\begin{array}{l}\text { Alcohol intake significantly increases } \\
\text { the risk for HCC; former drinkers } \\
\text { were more likely to develop HCC } \\
\text { than current drinkers. Furthermore, } \\
\text { intake }>60 \mathrm{~g} / \text { day led to a two-fold } \\
\text { increase in } \mathrm{HCC} \text {, a risk that was } \\
\text { further exacerbated by the presence of } \\
\text { viral hepatitis }\end{array}$ \\
\hline Monto et al. [22] & $\begin{array}{l}800 \text { patients with HCV with } \\
\text { history of alcohol use from } \\
\text { multiple VA hospitals }\end{array}$ & $\begin{array}{l}\text { Prospective assessment ( } 4 \text { years) } \\
\text { of the relationship between } \\
\text { alcohol intake and hepatitic } \\
\text { fibrosis }\end{array}$ & $\begin{array}{l}\text { Self-Report } \\
\text { Questionnaires of risk } \\
\text { factors for AUD/ SUD }\end{array}$ & $\begin{array}{l}\text { Heavy alcohol use associated with } \\
\text { greater risk of fibrosis than light or } \\
\text { moderate use, however, risk higher } \\
\text { with any alcohol use than among } \\
\text { patients with HCV who are abstinent. }\end{array}$ \\
\hline Fireman et al. [6] & $\begin{array}{l}293 \text { Veterans with HCV } \\
\text { scheduled for initial } \\
\text { Hepatology visits at a VA } \\
\text { hospital }\end{array}$ & $\begin{array}{l}\text { Prospective single assessment of } \\
\text { tri-morbidity of HCV, Depression } \\
\text { and substance use disorders. }\end{array}$ & $\begin{array}{l}\text { Alcohol Use Disorders } \\
\text { Identification Test } \\
\text { (AUDIT-C) }\end{array}$ & $\begin{array}{l}\text { Over } 30 \% \text { of Veterans with HCV had } \\
\text { AUDIT-C scores of } 4 \text { or greater } \\
\text { suggesting current harmful drinking. } \\
\text { Routine screening and early } \\
\text { interventions of AUDs may optimize } \\
\text { access to antiviral treatment and } \\
\text { decrease risk of liver disease } \\
\text { progression. }\end{array}$ \\
\hline
\end{tabular}

${ }^{1}$ Refer to Appendix A for list of measures associated with abbreviations.

Notes

-Original studies with $>15$ subjects were included in table.

-Studies with non-human subjects omitted.

-Literature Review studies were omitted.

Table 6. Treatment of HCV infection in patients with SUD.

\begin{tabular}{|c|c|c|c|c|}
\hline References & $\begin{array}{l}\text { Sample Size and } \\
\text { characteristics }\end{array}$ & Purpose of study & $\begin{array}{l}\text { Rating Scales for } \\
\text { Substance Use }\end{array}$ & Outcome \\
\hline $\begin{array}{l}\text { Okazaki et al. } \\
\text { [99] }\end{array}$ & $\begin{array}{l}39 \text { patients with HCV with and } \\
\text { without a history of habitual } \\
\text { drinking being treated for HCV }\end{array}$ & $\begin{array}{l}\text { Clinical trial assessing the } \\
\text { efficacy of IFN therapy } \\
\text { among drinkers and non- } \\
\text { drinkers }\end{array}$ & $\begin{array}{l}\text { Self-reported alcohol } \\
\text { intake. Heavy use } \\
\text { defined as greater } \\
\text { than } 70 \text { grams/day. } \\
\end{array}$ & $\begin{array}{l}\text { Antiviral therapy for } \mathrm{HCV} \text { was less effective } \\
\text { in heavy drinkers than in non-drinkers }\end{array}$ \\
\hline $\begin{array}{l}\text { Ohnishi et al. } \\
{[24]}\end{array}$ & $\begin{array}{l}95 \text { patients with } \mathrm{HCV} \text { and a } \\
\text { history of alcohol use, treated } \\
\text { with IFN therapy }\end{array}$ & $\begin{array}{l}\text { Clinical trial assessing the } \\
\text { efficacy of IFN therapy for } \\
\text { chronic hepatitis C among } \\
\text { habitual drinkers }\end{array}$ & $\begin{array}{l}\text { Degree of daily } \\
\text { alcohol consumption } \\
\text { and duration of } \\
\text { abstinence before } \\
\text { treatment }\end{array}$ & $\begin{array}{l}\text { Heavy drinking reduces the efficacy of IFN } \\
\text { therapy for chronic } \mathrm{HCV} \text {. }\end{array}$ \\
\hline $\begin{array}{l}\text { Loguercio et al. } \\
{[105]}\end{array}$ & $\begin{array}{l}245 \text { inpatients with HCV with } \\
\text { or without cirrhosis and a } \\
\text { history of alcohol use }\end{array}$ & $\begin{array}{l}\text { Retrospective cohort study } \\
\text { assessing alcohol and HCV } \\
\text { related liver damage. }\end{array}$ & Ethanol intake & $\begin{array}{l}\text { Less than } 50 \% \text { of subjects stopped drinking } \\
\text { after being diagnosed with chronic HCV. An } \\
\text { educational program on alcohol use in } \\
\text { chronic liver disease should be provided. }\end{array}$ \\
\hline $\begin{array}{l}\text { Dalgard et al. } \\
\text { [103] }\end{array}$ & $\begin{array}{l}27 \text { former injection drug users } \\
\text { successfully treated for HCV } \\
\text { (followed from a previous } \\
\text { clinical trial) }\end{array}$ & $\begin{array}{l}\text { Longitudinal assessment ( } 5 \\
\text { year follow up period) of } \\
\text { treatment outcomes }\end{array}$ & $\begin{array}{l}\text { Structured interview } \\
\text { of IDU behaviors }\end{array}$ & $\begin{array}{l}\text { The long-term outcome of HCV treatment in } \\
\text { former injection drug users was positive. } \\
\text { Despite frequent reinitiation of IDU all but } 1 \\
\text { remained HCV negative. }\end{array}$ \\
\hline $\begin{array}{l}\text { Kwiatkowski et } \\
\text { al. }[94]\end{array}$ & $\begin{array}{l}197 \text { injection drug users with } \\
\text { and without HCV (136 with } \\
\text { HCV and } 61 \text { without HCV) } \\
\text { recruited from urban settings }\end{array}$ & $\begin{array}{l}\text { Prospective assessment (1 } \\
\text { year) to document the } \\
\text { prevalence and awareness } \\
\text { of } \\
\mathrm{HCV}, \text { IDU and other risk } \\
\text { behaviors. }\end{array}$ & Self-Report & $\begin{array}{l}\text { Injection drug users with HCV who are } \\
\text { educated and aware of their HCV status are } \\
\text { less likely to engage in high risk behaviors } \\
\text { than injection drug users who are uneducated. }\end{array}$ \\
\hline
\end{tabular}




\begin{tabular}{|c|c|c|c|c|}
\hline References & $\begin{array}{l}\text { Sample Size and } \\
\text { characteristics }\end{array}$ & Purpose of study & $\begin{array}{l}\text { Rating Scales for } \\
\text { Substance Use }\end{array}$ & Outcome \\
\hline $\begin{array}{l}\text { Morrill et al. } \\
{[25]}\end{array}$ & $\begin{array}{l}208 \text { patients with HCV from a } \\
\text { primary care clinic }\end{array}$ & $\begin{array}{l}\text { Cross sectional assessment } \\
\text { of barriers to treatment in } \\
\text { patients with HCV. }\end{array}$ & \begin{tabular}{|l} 
Physician \\
assessment; review of \\
medical records
\end{tabular} & $\begin{array}{l}\text { Substance abuse and psychiatric } \\
\text { comorbidities were major reasons patients } \\
\text { were withheld from receiving antiviral } \\
\text { treatment. }\end{array}$ \\
\hline $\begin{array}{l}\text { Campbell et al. } \\
\text { [95] }\end{array}$ & $\begin{array}{l}598 \mathrm{HCV} \text { infected injection } \\
\text { drug users from an urban } \\
\text { population }\end{array}$ & $\begin{array}{l}\text { Prospective cohort study }(2 \\
\text { years) of problematic } \\
\text { alcohol use and disease } \\
\text { awareness in this population }\end{array}$ & $\begin{array}{l}\text { Clinical Interview, } \\
\text { Self-report, AUDIT, } \\
\text { CAGE Substance } \\
\text { Abuse Screening } \\
\text { Tool }\end{array}$ & $\begin{array}{l}\text { Despite reported understanding for the } \\
\text { increased risk of liver disease from alcohol } \\
\text { use, } 37 \% \text { of injection drug users in this } \\
\text { sample reported continuous and problematic } \\
\text { drinking. Major risk factors included } \\
\text { homelessness, use of multiple injection drugs, } \\
\text { history of alcohol treatment and depression. }\end{array}$ \\
\hline Rifai et al. [96] & $\begin{array}{l}78 \text { patients with HCV and } 260 \\
\text { without HCV attending a } \\
\text { substance abuse treatment } \\
\text { program at a VA hospital }\end{array}$ & $\begin{array}{l}\text { Longitudinal evaluation (1 } \\
\text { year) of the association } \\
\text { between HCV status and } \\
\text { substance abuse } \\
\text { rehabilitation outcomes }\end{array}$ & $\begin{array}{l}\text { Electronic and paper } \\
\text { medical records }\end{array}$ & $\begin{array}{l}\text { Patients with HCV and SUD who participate } \\
\text { in an SUD recovery program are more likely } \\
\text { to become and remain abstinent and more } \\
\text { likely to receive HCV treatment than HCV } \\
\text { infected patients with SUD who never } \\
\text { attended a substance-abuse treatment } \\
\text { program. }\end{array}$ \\
\hline $\begin{array}{l}\text { Huckans et al. } \\
{[100]}\end{array}$ & $\begin{array}{l}307,437 \text { Veterans with and } \\
\text { without HCV with and without } \\
\text { SUD (11,012 with HCV and } \\
47,614 \text { with SUD) from } \\
\text { multiple VA hospitals }\end{array}$ & $\begin{array}{l}\text { Retrospective chart review } \\
\text { assessing treatment } \\
\text { completion and response } \\
\text { rates }\end{array}$ & $\begin{array}{l}\text { Medical Records } \\
\text { Database }\end{array}$ & $\begin{array}{l}\text { HCV infected Veterans with and without } \\
\text { SUD respond to antiviral therapy at similar } \\
\text { rates. Veterans with HCV and SUD are } \\
\text { capable of successfully completing a course } \\
\text { of antiviral therapy. }\end{array}$ \\
\hline
\end{tabular}

${ }^{1}$ Refer to Appendix A for list of measures associated with abbreviations.

Notes

-Original studies with $>15$ subjects were included in table.

-Studies with non-human subjects omitted.

-Literature Review studies were omitted.

Table 7. Pain diagnoses in patients with HCV.

\begin{tabular}{|c|c|c|c|c|}
\hline References & $\begin{array}{l}\text { Sample Size and } \\
\text { Characteristics }\end{array}$ & Purpose of study & Rating Scales for Pain ${ }^{1}$ & Outcome \\
\hline $\begin{array}{l}\text { Rivera et al. } \\
\text { [29] }\end{array}$ & $\begin{array}{l}224 \text { patients with } \\
\text { Fibromyalgia syndrome (FS) } \\
\text { or Rheumatoid Arthritis } \\
\text { (RA), with and without } \\
\text { HCV- (110 with HCV, } 114 \\
\text { without) from an outpatient } \\
\text { rheumatology clinic. }\end{array}$ & $\begin{array}{l}\text { Prospective assessment of the } \\
\text { occurrence of fibromyalgia in } \\
\text { patients with active HCV } \\
\text { infection }\end{array}$ & $\begin{array}{l}\text { Physical examination and } 18 \\
\text { tender points }\end{array}$ & $\begin{array}{l}\text { Data suggest that there exists an } \\
\text { association between FM and active } \\
\mathrm{HCV} \text { infection in some of our patients }\end{array}$ \\
\hline $\begin{array}{l}\text { Barkhuizen et } \\
\text { al. [30] }\end{array}$ & $\begin{array}{l}239 \text { patients with and } \\
\text { without HCV (121 with } \\
\text { HCV and } 118 \text { without HCV) } \\
\text { attending a Hepatology } \\
\text { Clinics. }\end{array}$ & $\begin{array}{l}\text { Prospective assessment }(1 \\
\text { year) of fatigue and } \\
\text { musculoskeletal pain in } \mathrm{HCV} \\
\text { compared with other liver } \\
\text { diseases. }\end{array}$ & $\begin{array}{l}\text { Self-report questionnaire on } \\
\text { pain symptoms, severity and } \\
\text { location }\end{array}$ & $\begin{array}{l}\text { Musculoskeletal pain and fatigue are } \\
\text { frequent in patients with HCV and } \\
\text { may occur independent of severity of } \\
\text { liver disease, route of infection, or IFN } \\
\text { therapy. }\end{array}$ \\
\hline $\begin{array}{l}\text { Cacoub et al. } \\
{[33]}\end{array}$ & $\begin{array}{l}1614 \text { patients with } \mathrm{HCV} \\
\text { recruited from a hospital } \\
\text { clinic }\end{array}$ & $\begin{array}{l}\text { Prospective assessment of } \\
\text { clinical and biological } \\
\text { extra-hepatic manifestations of } \\
\text { HCV. }\end{array}$ & $\begin{array}{l}\text { Chart Review; Self Report; } \\
\text { Physician assessment }\end{array}$ & $\begin{array}{l}\text { Extra hepatic manifestations } \\
\text { are frequently observed in HCV } \\
\text { patients and involve the joints, } \\
\text { muscles, and skin. The most frequent } \\
\text { risk factors are advanced age, female } \\
\text { gender, and extensive liver fibrosis. }\end{array}$ \\
\hline $\begin{array}{l}\text { Goulding et al. } \\
{[34}\end{array}$ & $\begin{array}{l}77 \text { patients with HCV from a } \\
\text { hospital Hepatology clinic }\end{array}$ & $\begin{array}{l}\text { Prospective assessment of } \\
\text { rheumatological disease, in } \\
\text { different groups of patients } \\
\text { with chronic HCV infection. }\end{array}$ & $\begin{array}{l}\text { Medical history, Physical } \\
\text { Exam, Tender points, } \\
\text { Fibromyalgia Impact } \\
\text { Questionnaire (FIQ); self- } \\
\text { report }\end{array}$ & $\begin{array}{l}\text { Diagnoses of fibromyalgia are } \\
\text { common in patients with HCV. }\end{array}$ \\
\hline $\begin{array}{l}\text { Kozanoglu et } \\
\text { al. [113] }\end{array}$ & \begin{tabular}{|l|}
190 patients with and \\
without $\mathrm{HCV}$ ( 95 with $\mathrm{HCV}$ \\
and 95 without $\mathrm{HCV}$ ) from a \\
hospital clinic
\end{tabular} & $\begin{array}{l}\text { Prospective assessment of the } \\
\text { presence of Fibromyalgia } \\
\text { syndrome (FS) in patients with } \\
\text { HCV. }\end{array}$ & $\begin{array}{l}\text { Self-report, } 10 \text { CM Visual } \\
\text { Analogue Scale for Pain (10- } \\
\text { CM VAS), } 18 \text { tender point } \\
\text { scale and } 3 \text { control points }\end{array}$ & $\begin{array}{l}\text { Fibromyalgia, Sleep disturbance, } \\
\text { stiffness, headache, paresthesia and } \\
\text { fatigue were observed more frequently } \\
\text { in patients with HCV. }\end{array}$ \\
\hline
\end{tabular}




\begin{tabular}{|c|c|c|c|c|}
\hline References & $\begin{array}{l}\text { Sample Size and } \\
\text { Characteristics }\end{array}$ & Purpose of study & Rating Scales for Pain ${ }^{1}$ & Outcome \\
\hline $\begin{array}{l}\text { Silberbogen et } \\
\text { al. [31] }\end{array}$ & $\begin{array}{l}38 \text { Veterans with HCV from } \\
\text { a Hepatology clinic at a VA } \\
\text { hospital }\end{array}$ & $\begin{array}{l}\text { Retrospective assessment of } \\
\text { the scope and impact of pain } \\
\text { and pain functioning }\end{array}$ & $\begin{array}{l}\text { McGill Pain Questionnaire - } \\
\text { Short Form (MPQ-SF) } \\
\text { Multidimensional Pain } \\
\text { Inventory (MPI) }\end{array}$ & $\begin{array}{l}\text { Pain is prevalent within this } \\
\text { population. HCV-positive Veterans } \\
\text { who experience persistent pain have } \\
\text { significant depressive symptoms and } \\
\text { engage in certain high risk behaviors, } \\
\text { such as cigarette smoking and alcohol } \\
\text { use. }\end{array}$ \\
\hline $\begin{array}{l}\text { Morasco et al. } \\
{[35}\end{array}$ & $\begin{array}{l}49 \text { Veterans with HCV from } \\
\text { a community sample for a } \\
\text { larger study on HCV at a VA } \\
\text { hospital }\end{array}$ & $\begin{array}{l}\text { Assessment of biological and } \\
\text { psychological variables with } \\
\text { pain intensity and pain } \\
\text { functioning in patients with } \\
\text { HCV }\end{array}$ & $\begin{array}{l}\text { Clinical Interview, Medical } \\
\text { records, Severity of } \\
\text { Dependence Scales (SDS), } \\
\text { SF-36, Numeric Rating Scale } \\
\text { for pain intensity (NRS) with } \\
\text { a scale of } 0 \text { to } 10\end{array}$ & $\begin{array}{l}\text { Over half of Veterans had a current } \\
\text { pain-related condition and } \\
\text { psychosocial variables, particularly } \\
\text { depression severity, accounted for } \\
\text { variance in pain intensity and pain } \\
\text { functioning. }\end{array}$ \\
\hline $\begin{array}{l}\text { Lovejoy et al. } \\
{[111]}\end{array}$ & $\begin{array}{l}101 \text { Veterans with HCV } \\
\text { from a single VA Hospital }\end{array}$ & $\begin{array}{l}\text { Cross sectional assessment } \\
\text { and retrospective chart review } \\
\text { of chronic pain in Veterans } \\
\text { with HCV }\end{array}$ & $\begin{array}{l}\text { Medical Service utilization } \\
\text { data }\end{array}$ & $\begin{array}{l}64 \% \text { of Veterans with HCV } \\
\text { experienced chronic pain. Veterans } \\
\text { with HCV and chronic pain utilized } \\
\text { more health care services compared to } \\
\text { Veterans with HCV and no chronic } \\
\text { pain. }\end{array}$ \\
\hline $\begin{array}{l}\text { Mohammad et } \\
\text { al. [118] }\end{array}$ & $\begin{array}{l}185 \text { patients with } \mathrm{HCV} \text { from } \\
\text { a single Hepatology clinic at } \\
\text { a University Hospital }\end{array}$ & $\begin{array}{l}\text { Cross sectional assessment to } \\
\text { determine the prevalence of } \\
\text { Fibromyalgia syndrome (FS) } \\
\text { in patients with HCV }\end{array}$ & $\begin{array}{l}\text { Physician assessment and } \\
\text { review of medical records }\end{array}$ & $\begin{array}{l}\text { This study reveals a high prevalence of } \\
\text { FS }(57 \%) \\
\text { among subjects with chronic HCV } \\
\text { infection, one third of whom reported } \\
\text { some degree of functional impairment } \\
\text { and poorer quality of life. }\end{array}$ \\
\hline $\begin{array}{l}\text { Morasco et al. } \\
{[36]}\end{array}$ & $\begin{array}{l}119 \text { patients infected with } \\
\text { HCV from a single VA } \\
\text { hospital }\end{array}$ & $\begin{array}{l}\text { Prospective evaluation (2 } \\
\text { years) of biopsychosocial } \\
\text { factors and pain among } \\
\text { patients with HCV. }\end{array}$ & $\begin{array}{l}\text { Self-Report; MPI, Pain } \\
\text { Catastrophizing Scale (PCS), } \\
\text { Chronic Pain Self Efficacy } \\
\text { Scale (CPSS), Chronic Pain } \\
\text { Coping Inventory (CPCI) }\end{array}$ & $\begin{array}{l}\text { Biopsychosocial factors such as pain } \\
\text { catastrophizing and social support } \\
\text { significantly affected pain severity and } \\
\text { pain interference in patients with } \\
\text { HCV. }\end{array}$ \\
\hline
\end{tabular}

${ }^{1}$ Refer to Appendix A for list of measures associated with abbreviations.

Notes

-Original studies with $>15$ subjects were included in table.

-Studies with non-human subjects omitted.

-Literature Review studies were omitted.

Additionally, DAAs including ombitasvir, ritonavir, daclatasvir and ledispasvir are available as interferon-free regimens and largely eliminate the risk of side effects such as depression, muscle aches and fatigue which are often associated with interferon. As a result, patients who may have previously been considered ineligible or unlikely to successfully complete treatment may now be treated. While the development of side effects such as depression, pain, and fatigue is significantly minimized with these newer regimens, abstinence from alcohol and other substances is still recommended before treatment for HCV begins. Further research will be required to assess the clinical impact of these newer medications on pain, depression, and SUDs.

\section{CONCLUSION}

In conclusion, the present review highlights significant strides made in our empirical and clinical understanding of the complex interplay between $\mathrm{HCV}$ and depression, pain, and substance abuse. Additional research related to appropriate assessment and treatment of $\mathrm{HCV}$ and its comorbidities may help improve prospects for successful treatment of medical and mental health concerns.

\section{APPENDIX A}

\section{List of Abbreviations}

$\begin{array}{ll}\text { 10-CM VAS } & =10 \mathrm{CM} \text { Visual Analogue Scale for Pain } \\ \text { AUD } & =\text { Alcohol use Disorder } \\ \text { AUDIT-C } & =\text { Alcohol use Disorders Identification Test } \\ \text { BDI } & =\text { Beck Depression Inventory } \\ \text { CAGE } & =\text { CAGE Substance Abuse Screening Tool } \\ \text { CES-D -Center for Epidemiologic Studies of Depression } & =\text { Test for Depression }\end{array}$




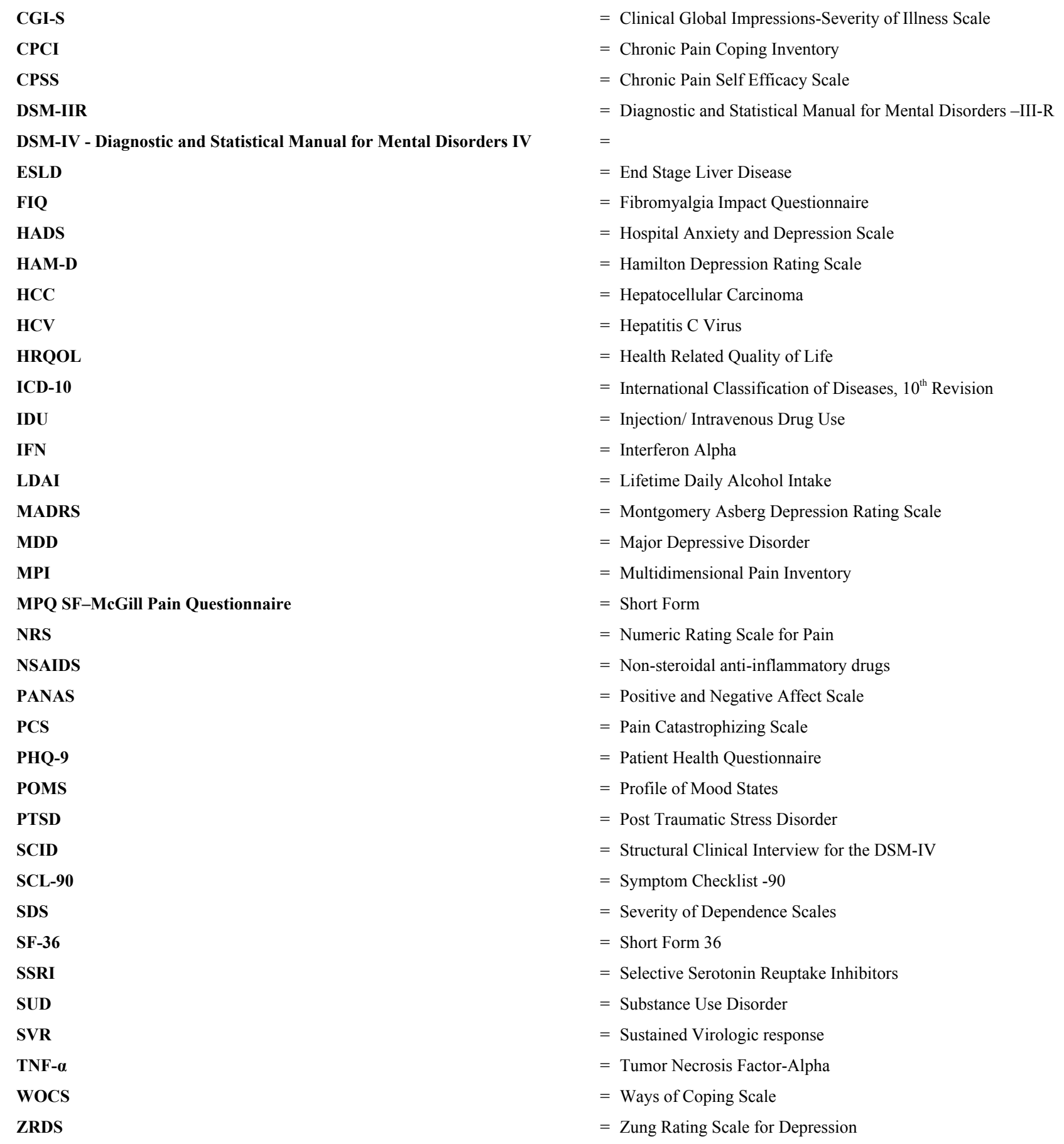

\section{CONFLICT OF INTEREST}

The authors confirm that this article content has no conflict of interest.

\section{ACKNOWLEDGEMENTS}

Declared None.

\section{REFERENCES}

[1] Alter MJ, Kruszon-Moran D, Nainan OV, et al. The prevalence of hepatitis C virus infection in the United States, 1988 through 1994. N Engl J Med 1999; 341(8): 556-62. [PMID: 10451460]

[2] Alter MJ. Epidemiology of hepatitis C. Hepatology 1997; 26(3)(Suppl. 1): 62S-5. [PMID: 9305666] 
[3] Lauer GM, Walker BD. Hepatitis C virus infection. N Engl J Med 2001; 345(1): 41-52. [PMID: 11439948]

[4] Dieperink E, Willenbring M, Ho SB. Neuropsychiatric symptoms associated with hepatitis C and interferon alpha: A review. Am J Psychiatry 2000; 157(6): 867-76.

[PMID: 10831463]

[5] Dwight MM, Kowdley KV, Russo JE, Ciechanowski PS, Larson AM, Katon WJ. Depression, fatigue, and functional disability in patients with chronic hepatitis C. J Psychosom Res 2000; 49(5): 311-7. [PMID: 11164055]

[6] Fireman M, Indest DW, Blackwell A, Whitehead AJ, Hauser P. Addressing tri-morbidity (hepatitis C, psychiatric disorders, and substance use): the importance of routine mental health screening as a component of a comanagement model of care. Clin Infect Dis 2005; 40(Suppl. 5): S286-91. [PMID: 15768336]

[7] Golden J, O’Dwyer AM, Conroy RM. Depression and anxiety in patients with hepatitis C: prevalence, detection rates and risk factors. Gen Hosp Psychiatry 2005; 27(6): 431-8. [PMID: 16271658]

[8] Nelligan J, Loftis JM, Matthews AM, Zucker Z, Linke A, Hauser P. Depression co-morbidity and antidepressant use in veterans with chronic hepatitis C. J Clin Psychiatry 2008; 69(5): 810-6.

[PMID: 18426262]

[9] Patterson AL, Morasco BJ, Fuller BE, Indest DW, Loftis JM, Hauser P. Screening for depression in patients with hepatitis C using the Beck Depression Inventory-II: do somatic symptoms compromise validity? Gen Hosp Psychiatry 2011; 33(4): 354-62. [PMID: 21762832]

[10] McHutchison JG, Gordon SC, Schiff ER, et al. Interferon alfa-2b alone or in combination with ribavirin as initial treatment for chronic hepatitis C. N Engl J Med 1998; 339(21): 1485-92.

[PMID: 9819446]

[11] Hauser P, Khosla J, Aurora H, et al. A prospective study of the incidence and open-label treatment of interferon-induced major depressive disorder in patients with hepatitis C. Mol Psychiatry 2002; 7(9): 942-7.

[PMID: 12399946]

[12] Fried MW, Shiffman ML, Reddy KR, et al. Peginterferon alfa-2a plus ribavirin for chronic hepatitis C virus infection. N Engl J Med 2002; 347(13): 975-82. [PMID: 12324553]

[13] Angelino AF, Treisman GJ. Evidence-informed assessment and treatment of depression in HCV and interferon-treated patients. Int Rev Psychiatry 2005; 17(6): 471-6.

[PMID: 16401545]

[14] Janssen HL, Brouwer JT, van der Mast RC, Schalm SW. Suicide associated with alfa-interferon therapy for chronic viral hepatitis. J Hepatol 1994; 21(2): 241-3. [PMID: 7989716]

[15] El-Serag HB, Kunik M, Richardson P, Rabeneck L. Psychiatric disorders among veterans with hepatitis C infection. Gastroenterology 2002; 123(2): 476-82. [PMID: 12145801]

[16] Huckans MS, Blackwell AD, Harms TA, Hauser P. Management of hepatitis C disease among VA patients with schizophrenia and substance use disorders. Psychiatr Serv 2006; 57(3): 403-6. [PMID: 16525001]

[17] Corrao G, Aricò S. Independent and combined action of hepatitis C virus infection and alcohol consumption on the risk of symptomatic liver cirrhosis. Hepatology 1998; 27(4): 914-9. [PMID: 9537428]

[18] Ostapowicz G, Watson KJ, Locarnini SA, Desmond PV. Role of alcohol in the progression of liver disease caused by hepatitis C virus infection. Hepatology 1998; 27(6): 1730-5. [PMID: 9620350]

[19] Khan KN, Yatsuhashi H. Effect of alcohol consumption on the progression of hepatitis C virus infection and risk of hepatocellular carcinoma in Japanese patients. Alcohol Alcohol 2000; 35(3): 286-95. [PMID: 10869250]

[20] Peters MG, Terrault NA. Alcohol use and hepatitis C. Hepatology 2002; 36(5)(Suppl. 1): S220-5. [PMID: 12407597]

[21] Donato F, Tagger A, Gelatti U, et al. Alcohol and hepatocellular carcinoma: the effect of lifetime intake and hepatitis virus infections in men and women. Am J Epidemiol 2002; 155(4): 323-31. [PMID: 11836196]

[22] Monto A, Patel K, Bostrom A, et al. Risks of a range of alcohol intake on hepatitis C-related fibrosis. Hepatology 2004; 39(3): 826-34. 
[PMID: 14999703]

[23] Loftis JM, Matthews AM, Hauser P. Psychiatric and substance use disorders in individuals with hepatitis C: epidemiology and management. Drugs 2006; 66(2): 155-74. [PMID: 16451091]

[24] Ohnishi K, Matsuo S, Matsutani K, et al. Interferon therapy for chronic hepatitis C in habitual drinkers: comparison with chronic hepatitis C in infrequent drinkers. Am J Gastroenterol 1996; 91(7): 1374-9. [PMID: 8677998]

[25] Morrill JA, Shrestha M, Grant RW. Barriers to the treatment of hepatitis C. Patient, provider, and system factors. J Gen Intern Med 2005; 20(8): 754-8. [PMID: 16050887]

[26] Chainuvati S, Khalid SK, Kancir S, et al. Comparison of hepatitis C treatment patterns in patients with and without psychiatric and/or substance use disorders. J Viral Hepat 2006; 13(4): 235-41. [PMID: 16611189]

[27] Matthews AM, Huckans MS, Blackwell AD, Hauser P. Hepatitis C testing and infection rates in bipolar patients with and without comorbid substance use disorders. Bipolar Disord 2008; 10(2): 266-70. [PMID: 18271905]

[28] Sylvestre DL, Loftis JM, Hauser P, et al. Co-occurring Hepatitis C, substance use, and psychiatric illness: treatment issues and developing integrated models of care. J Urban Health 2004; 81(4): 719-34. [PMID: 15466851]

[29] Rivera J, de Diego A, Trinchet M, García Monforte A. Fibromyalgia-associated hepatitis C virus infection. Br J Rheumatol 1997; 36(9): 981-5. [PMID: 9376995]

[30] Barkhuizen A, Rosen HR, Wolf S, Flora K, Benner K, Bennett RM. Musculoskeletal pain and fatigue are associated with chronic hepatitis C: a report of 239 hepatology clinic patients. Am J Gastroenterol 1999; 94(5): 1355-60. [PMID: 10235218]

[31] Silberbogen AK, Janke EA, Hebenstreit C. A closer look at pain and hepatitis C: preliminary data from a veteran population. J Rehabil Res Dev 2007; 44(2): 231-44. [PMID: 17551875]

[32] Whitehead AJ, Dobscha SK, Morasco BJ, Ruimy S, Bussell C, Hauser P. Pain, substance use disorders and opioid analgesic prescription patterns in veterans with hepatitis C. J Pain Symptom Manage 2008; 36(1): 39-45.

[PMID: 18358690]

[33] Cacoub P, Poynard T, Ghillani P, et al. Extrahepatic manifestations of chronic hepatitis C. MULTIVIRC Group. Multidepartment Virus C. Arthritis Rheum 1999; 42(10): 2204-12. [PMID: 10524695]

[34] Goulding C, O’Connell P, Murray FE. Prevalence of fibromyalgia, anxiety and depression in chronic hepatitis C virus infection: relationship to RT-PCR status and mode of acquisition. Eur J Gastroenterol Hepatol 2001; 13(5): 507-11. [PMID: 11396529]

[35] Morasco BJ, Huckans M, Loftis JM, et al. Predictors of pain intensity and pain functioning in patients with the hepatitis C virus. Gen Hosp Psychiatry 2010; 32(4): 413-8. [PMID: 20633746]

[36] Morasco BJ, Lovejoy TI, Turk DC, Crain A, Hauser P, Dobscha SK. Biopsychosocial factors associated with pain in veterans with the hepatitis C virus. J Behav Med 2014; 37(5): 902-11. [PMID: 24338521]

[37] Tsui JI, Cheng DM, Libman H, Bridden C, Samet J, Hepatitis C. Hepatitis C virus infection is associated with painful symptoms in HIVinfected adults. AIDS Care 2012; 24(7): 820-7 [PMID: 22272656]

[38] Lee DH, Jamal H, Regenstein FG, Perrillo RP. Morbidity of chronic hepatitis C as seen in a tertiary care medical center. Dig Dis Sci 1997; 42(1): 186-91. [PMID: 9009136]

[39] Singh N, Gayowski T, Wagener MM, Marino IR. Vulnerability to psychologic distress and depression in patients with end-stage liver disease due to hepatitis C virus. Clin Transplant 1997; 11(5 Pt 1): 406-11. [PMID: 9361931]

[40] Foster GR, Goldin RD, Thomas HC. Chronic hepatitis C virus infection causes a significant reduction in quality of life in the absence of cirrhosis. Hepatology 1998; 27(1): 209-12 [PMID: 9425939]

[41] McHutchison JG, Ware JE Jr, Bayliss MS, et al. The effects of interferon alpha-2b in combination with ribavirin on health related quality of life and work productivity. J Hepatol 2001; 34(1): 140-7. [PMID: 11211891] 
[42] Carithers RL Jr, Sugano D, Bayliss M. Health assessment for chronic HCV infection: results of quality of life. Dig Dis Sci 1996; 41(12)(Suppl.): 75S-80S. [PMID: 9011480]

[43] Gallegos-Orozco JF, Fuentes AP, Gerardo Argueta J, et al. Health-related quality of life and depression in patients with chronic hepatitis C. Arch Med Res 2003; 34(2): 124-9. [PMID: 12700008]

[44] Adinolfi LE, Nevola R, Lus G, et al. Chronic hepatitis C virus infection and neurological and psychiatric disorders: an overview. World J Gastroenterol 2015; 21(8): 2269-80. [PMID: 25741133]

[45] Regier DA, Farmer ME, Rae DS, et al. Comorbidity of mental disorders with alcohol and other drug abuse. Results from the Epidemiologic Catchment Area (ECA) Study. JAMA 1990; 264(19): 2511-8. [PMID: 2232018]

[46] Dickey B, Azeni H. Persons with dual diagnoses of substance abuse and major mental illness: their excess costs of psychiatric care. Am J Public Health 1996; 86(7): 973-7. [PMID: 8669521]

[47] Kessler RC, Crum RM, Warner LA, Nelson CB, Schulenberg J, Anthony JC. Lifetime co-occurrence of DSM-III-R alcohol abuse and dependence with other psychiatric disorders in the National Comorbidity Survey. Arch Gen Psychiatry 1997; 54(4): $313-21$. [PMID: 9107147]

[48] Grant BF, Stinson FS, Dawson DA, et al. Prevalence and co-occurrence of substance use disorders and independentMood and anxiety disorders. Arch Gen Psychiatry 2004; 61(8): 807-16. [PMID: 15289279]

[49] Kessler RC, Avenevoli S, Costello J, et al. Prevalence, severity, and comorbidity of 12-month DSM-IV disorders in the national comorbidity survey replication. Arch Gen Psychiatry 2012; 69(4): 381-9. [PMID: 22474106]

[50] Bassuk EL, Buckner JC, Perloff JN, Bassuk SS. Prevalence of mental health and substance use disorders among homeless and low-income housed mothers. Am J Psychiatry 1998; 155(11): 1561-4. [PMID: 9812118]

[51] Beijer U, Wolf A, Fazel S. Prevalence of tuberculosis, hepatitis C virus, and HIV in homeless people: a systematic review and meta-analysis. Lancet Infect Dis 2012; 12(11): 859-70. [PMID: 22914343]

[52] Capuron L, Ravaud A. Prediction of the depressive effects of interferon alfa therapy by the patient's initial affective state. N Engl J Med 1999; 340(17): 1370 . [PMID: 10223879]

[53] Hauser P, Loftis JM, Dieperink EW, Garcia-Tsao G, Rigsby MO, Willenbring ML. VHA HCRC Depression and Substance Use Disorders in Chronic Hepatitis C. Fed Prac 2004; pp. 90-101.

[54] Loftis JM, Socherman RE, Howell CD, et al. Association of interferon-alpha-induced depression and improved treatment response in patients with hepatitis C. Neurosci Lett 2004; 365(2): 87-91.

[PMID: 15245784]

[55] Davis GL, Esteban-Mur R, Rustgi V, et al. Interferon alfa-2b alone or in combination with ribavirin for the treatment of relapse of chronic hepatitis C. N Engl J Med 1998; 339(21): 1493-9. [PMID: 9819447]

[56] Manns MP, McHutchison JG, Gordon SC, et al. Peginterferon alfa-2b plus ribavirin compared with interferon alfa-2b plus ribavirin for initial treatment of chronic hepatitis C: a randomised trial. Lancet 2001; 358(9286): 958-65. [PMID: 11583749]

[57] Dieperink E, Ho SB, Thuras P, Willenbring ML. A prospective study of neuropsychiatric symptoms associated with interferon-alpha-2b and ribavirin therapy for patients with chronic hepatitis C. Psychosomatics 2003; 44(2): 104-12. [PMID: 12618532]

[58] Morikawa O, Sakai N, Obara H, Saito N. Effects of interferon-alpha, interferon-gamma and cAMP on the transcriptional regulation of the serotonin transporter. Eur J Pharmacol 1998; 349(2-3): 317-24. [PMID: 9671113]

[59] Kamata M, Higuchi H, Yoshimoto M, Yoshida K, Shimizu T. Effect of single intracerebroventricular injection of alpha-interferon on monoamine concentrations in the rat brain. Eur Neuropsychopharmacol 2000; 10(2): 129-32. [PMID: 10706995]

[60] Bonaccorso S, Puzella A, Marino V, et al. Immunotherapy with interferon-alpha in patients affected by chronic hepatitis C induces an intercorrelated stimulation of the cytokine network and an increase in depressive and anxiety symptoms. Psychiatry Res 2001; 105(1-2): 45-55.

[PMID: 11740974] 
[61] Loftis JM, Huckans M, Ruimy S, Hinrichs DJ, Hauser P. Depressive symptoms in patients with chronic hepatitis C are correlated with elevated plasma levels of interleukin-1beta and tumor necrosis factor-alpha. Neurosci Lett 2008; 430(3): 264-8. [PMID: 18063307]

[62] Song C, Lin A, Bonaccorso S, et al. The inflammatory response system and the availability of plasma tryptophan in patients with primary sleep disorders and major depression. J Affect Disord 1998; 49(3): 211-9. [PMID: 9629951]

[63] Depino A, Ferrari C, Pott Godoy MC, Tarelli R, Pitossi FJ. Differential effects of interleukin-1beta on neurotoxicity, cytokine induction and glial reaction in specific brain regions. J Neuroimmunol 2005; 168(1-2): 96-110. [PMID: 16112750]

[64] Levenson JL, Fallon HJ. Fluoxetine treatment of depression caused by interferon-alpha. Am J Gastroenterol 1993; 88(5): 760-1. [PMID: 8480744]

[65] Gleason OC, Yates WR. Five cases of interferon-alpha-induced depression treated with antidepressant therapy. Psychosomatics 1999; 40(6): 510-2. [PMID: 10581980]

[66] Schramm TM, Lawford BR, Macdonald GA, Cooksley WG. Sertraline treatment of interferon-alfa-induced depressive disorder. Med J Aust 2000; 173(7): 359-61. [PMID: 11062791]

[67] Malek-Ahmadi P, Ghandour E. Bupropion for treatment of interferon-induced depression. Ann Pharmacother 2004; 38(7-8): 1202-5. [PMID: 15150377]

[68] Schaefer M, Schwaiger M, Garkisch AS, et al. Prevention of interferon-alpha associated depression in psychiatric risk patients with chronic hepatitis C. J Hepatol 2005; 42(6): 793-8. [PMID: 15885349]

[69] Gleason OC, Yates WR, Isbell MD, Philipsen MA. An open-label trial of citalopram for major depression in patients with hepatitis C. J Clin Psychiatry 2002; 63(3): 194-8.

[PMID: 11926717]

[70] Hauser P, Soler R, Reed S, et al. Prophylactic treatment of depression induced by interferon-alpha. Psychosomatics 2000; 41(5): 439-41. [PMID: 11015632]

[71] Kraus MR, Schäfer A, Al-Taie O, Scheurlen M. Prophylactic SSRI during interferon alpha re-therapy in patients with chronic hepatitis C and a history of interferon-induced depression. J Viral Hepat 2005; 12(1): 96-100. [PMID: 15655055]

[72] Galvão-de Almeida A, Guindalini C, Batista-Neves S, de Oliveira IR, Miranda-Scippa A, Quarantini LC. Can antidepressants prevent interferon-alpha-induced depression? A review of the literature. Gen Hosp Psychiatry 2010; 32(4): 401-5. [PMID: 20633744]

[73] Hauser P, Morasco BJ, Linke A, et al. Antiviral completion rates and sustained viral response in hepatitis C patients with and without preexisting major depressive disorder. Psychosomatics 2009; 50(5): 500-5.

[PMID: 19855036]

[74] Kraus MR, Schäfer A, Schöttker K, et al. Therapy of interferon-induced depression in chronic hepatitis C with citalopram: a randomised, double-blind, placebo-controlled study. Gut 2008; 57(4): 531-6. [PMID: 18079286]

[75] Morasco BJ, Rifai MA, Loftis JM, Indest DW, Moles JK, Hauser P. A randomized trial of paroxetine to prevent interferon-alpha-induced depression in patients with hepatitis C. J Affect Disord 2007; 103(1-3): 83-90. [PMID: 17292481]

[76] Lands WE. Cellular signals in alcohol-induced liver injury: a review. Alcohol Clin Exp Res 1995; 19(4): 928-38. [PMID: 7485841]

[77] Raynard B, Balian A, Fallik D, et al. Risk factors of fibrosis in alcohol-induced liver disease. Hepatology 2002; 35(3): 635-8. [PMID: 11870378]

[78] Szabo G, Lippai D. Converging actions of alcohol on liver and brain immune signaling. Int Rev Neurobiol 2014; 118(118): 359-80. [PMID: 25175869]

[79] Leclercq S, Matamoros S, Cani PD, et al. Intestinal permeability, gut-bacterial dysbiosis, and behavioral markers of alcohol-dependence severity. Proc Natl Acad Sci USA 2014; 111(42): E4485-93. [PMID: 25288760]

[80] Vadnie CA, Park JH, Abdel Gawad N, Ho AM, Hinton DJ, Choi DS. Gut-brain peptides in corticostriatal-limbic circuitry and alcohol use disorders. Front Neurosci 2014; 8: 288. [PMID: 25278825]

[81] Morasco BJ, Loftis JM, Indest DW, et al. Prophylactic antidepressant treatment in patients with hepatitis C on antiviral therapy: a doubleblind, placebo-controlled trial. Psychosomatics 2010; 51(5): 401-8.

[PMID: 20833939] 
[82] Jamal MM, Morgan TR. Liver disease in alcohol and hepatitis C. Best Pract Res Clin Gastroenterol 2003; 17(4): 649-62. [PMID: 12828960]

[83] Roudot-Thorval F, Bastie A, Pawlotsky JM, Dhumeaux D. The study group for the prevalence and the epidemiology of hepatitis C virus. Hepatology 1997; 26: 485-90. [PMID: 9252163]

[84] Kubo S, Kinoshita H, Hirohashi K, et al. High malignancy of hepatocellular carcinoma in alcoholic patients with hepatitis C virus. Surgery 1997; 121(4): 425-9. [PMID: 9122873]

[85] Serfaty L, Chazouillères O, Poujol-Robert A, et al. Risk factors for cirrhosis in patients with chronic hepatitis C virus infection: results of a case-control study. Hepatology 1997; 26(3): 776-9. [PMID: 9303512]

[86] Wiley TE, McCarthy M, Breidi L, McCarthy M, Layden TJ. Impact of alcohol on the histological and clinical progression of hepatitis C infection. Hepatology 1998; 28(3): 805-9. [PMID: 9731576]

[87] Harris DR, Gonin R, Alter HJ, et al. The relationship of acute transfusion-associated hepatitis to the development of cirrhosis in the presence of alcohol abuse. Ann Intern Med 2001; 134(2): 120-4. [PMID: 11177315]

[88] Westin J, Lagging LM, Spak F, et al. Moderate alcohol intake increases fibrosis progression in untreated patients with hepatitis C virus infection. J Viral Hepat 2002; 9(3): 235-41. [PMID: 12010513]

[89] Edlin BR, Seal KH, Lorvick J, et al. Is it justifiable to withhold treatment for hepatitis C from illicit-drug users? N Engl J Med 2001; 345(3): 211-5. [PMID: 11463019]

[90] Centers for Disease Control and Prevention Surveillance for Viral Hepatitis - United States, Available from http://www.cdc.gov/hepatitis/ Statistics/2011Surveillance/Commentary.htm\#hepC 2014 [Accessed on 1/24/2015];

[91] Sorensen JL, Masson CL, Perlman DC. HIV/hepatitis prevention in drug abuse treatment programs: guidance from research. Sci Pract Perspect 2002; 1(1): 4-11. [PMID: 18567957]

[92] Hagan H, Des Jarlais DC. HIV and HCV infection among injecting drug users. Mt Sinai J Med 2000; 67(5-6): 423-8. [PMID: 11064493]

[93] Davis GL, Rodrigue JR. Treatment of chronic hepatitis C in active drug users. N Engl J Med 2001; 345(3): $215-7$. [PMID: 11463020]

[94] Kwiatkowski CF, Fortuin Corsi K, Booth RE. The association between knowledge of hepatitis C virus status and risk behaviors in injection drug users. Addiction 2002; 97(10): 1289-94. [PMID: 12359033]

[95] Campbell JV, Hagan H, Latka MH, et al. High prevalence of alcohol use among hepatitis C virus antibody positive injection drug users in three US cities. Drug Alcohol Depend 2006; 81(3): 259-65. [PMID: 16129567]

[96] Rifai MA, Moles JK, Lehman LP, Van der Linden BJ, Hepatitis C. Hepatitis C screening and treatment outcomes in patients with substance use/dependence disorders. Psychosomatics 2006; 47(2): 112-21. [PMID: 16508022]

[97] Cawthorne CH, Rudat KR, Burton MS, et al. Limited success of HCV antiviral therapy in United States veterans. Am J Gastroenterol 2002; 97(1): 149-55. [PMID: 11808940]

[98] Chainuvati S, Khalid SK, Kancir S, et al. Comparison of hepatitis C treatment patterns in patients with and without psychiatric and/or substance use disorders. J Viral Hepat 2006; 13(4): 235-41. [PMID: 16611189]

[99] Okazaki T, Yoshihara H, Suzuki K, et al. Efficacy of interferon therapy in patients with chronic hepatitis C. Comparison between nondrinkers and drinkers. Scand J Gastroenterol 1994; 29(11): 1039-43. [PMID: 7871371]

[100] Huckans MS, Loftis JM, Blackwell AD, Linke A, Hauser P. Interferon alpha therapy for hepatitis C: treatment completion and response rates among patients with substance use disorders. Subst Abuse Treat Prev Policy 2007; 2(4): 4. [PMID: 17222348]

[101] Schaefer M, Heinz A, Backmund M. Treatment of chronic hepatitis C in patients with drug dependence: time to change the rules? Addiction 2004; 99(9): 1167-75.

[PMID: 15317637] 
[102] Schaefer M, Schmidt F, Folwaczny C, et al. Adherence and mental side effects during hepatitis C treatment with interferon alfa and ribavirin in psychiatric risk groups. Hepatology 2003; 37(2): 443-51. [PMID: 12540795]

[103] Dalgard O, Bjøro K, Hellum K, et al. Treatment of chronic hepatitis C in injecting drug users: 5 years' follow-up. Eur Addict Res 2002; 8(1): 45-9. [PMID: 11818693]

[104] Dieperink E, Fuller B, Isenhart C, et al. Efficacy of motivational enhancement therapy on alcohol use disorders in patients with chronic hepatitis C: a randomized controlled trial. Addiction 2014; 109(11): 1869-77. [PMID: 25040898]

[105] Loguercio C, Di Pierro M, Di Marino MP, et al. Drinking habits of subjects with hepatitis C virus-related chronic liver disease: prevalence and effect on clinical, virological and pathological aspects. Alcohol Alcohol 2000; 35(3): 296-301. [PMID: 10869251]

[106] Edlin BR, Kresina TF, Raymond DB, et al. Overcoming barriers to prevention, care, and treatment of hepatitis C in illicit drug users. Clin Infect Dis 2005; 40(Suppl. 5): S276-85. [PMID: 15768335]

[107] Demyttenaere K, Bruffaerts R, Lee S, et al. Mental disorders among persons with chronic back or neck pain: results from the World Mental Health Surveys. Pain 2007; 129(3): 332-42. [PMID: 17350169]

[108] Breivik H, Collett B, Ventafridda V, Cohen R, Gallacher D. Survey of chronic pain in Europe: prevalence, impact on daily life, and treatment. Eur J Pain 2006; 10(4): 287-333. [PMID: 16095934]

[109] Blyth FM, March LM, Brnabic AJ, Cousins MJ. Chronic pain and frequent use of health care. Pain 2004; 111(1-2): 51-8. [PMID: 15327808]

[110] Gatchel RJ, Peng YB, Peters ML, Fuchs PN, Turk DC. The biopsychosocial approach to chronic pain: scientific advances and future directions. Psychol Bull 2007; 133(4): 581-624. [PMID: 17592957]

[111] Lovejoy TI, Dobscha SK, Cavanagh R, Turk DC, Morasco BJ. Chronic pain treatment and health service utilization of veterans with hepatitis C virus infection. Pain Med 2012; 13(11): 1407-16.

[PMID: 22958315]

[112] Rogal SS, Winger D, Bielefeldt K, Szigethy E. Pain and opioid use in chronic liver disease. Dig Dis Sci 2013; 58(10): 2976-85. [PMID: 23512406]

[113] Kozanoglu E, Canataroglu A, Abayli B, Colakoglu S, Goncu K. Fibromyalgia syndrome in patients with hepatitis C infection. Rheumatol Int 2003; 23(5): 248-51. [PMID: 14504918]

[114] Morasco BJ, Duckart JP, Dobscha SK. Adherence to clinical guidelines for opioid therapy for chronic pain in patients with substance use disorder. J Gen Intern Med 2011; 26(9): 965-71. [PMID: 21562923]

[115] Thompson ME, Barkhuizen A. Fibromyalgia, hepatitis C infection, and the cytokine connection. Curr Pain Headache Rep 2003 ; 7(5): $342-7$. [PMID: 12946286]

[116] Tunks ER, Crook J, Weir R. Epidemiology of chronic pain with psychological comorbidity: prevalence, risk, course, and prognosis. Can J Psychiatry 2008; 53(4): 224-34. [PMID: 18478825]

[117] Barry DT, Pilver C, Potenza MN, Desai RA. Prevalence and psychiatric correlates of pain interference among men and women in the general population. J Psychiatr Res 2012; 46(1): 118-27. [PMID: 21944430]

[118] Mohammad A, Carey JJ, Storan E, Scarry M, Coughlan RJ, Lee JM. Prevalence of fibromyalgia among patients with chronic hepatitis C infection: relationship to viral characteristics and quality of life. J Clin Gastroenterol 2012; 46(5): 407-12. [PMID: 22499073]

[119] Larson AM, Polson J, Fontana RJ, et al. Acetaminophen-induced acute liver failure: results of a United States multicenter, prospective study. Hepatology 2005; 42(6): 1364-72. [PMID: 16317692]

[120] Dunn KM, Saunders KW, Rutter CM, et al. Opioid prescriptions for chronic pain and overdose: a cohort study. Ann Intern Med 2010; 152(2): 85-92. [PMID: 20083827]

[121] Bohnert AS, Valenstein M, Bair MJ, et al. Association between opioid prescribing patterns and opioid overdose-related deaths. JAMA 2011; 305(13): 1315-21.

[PMID: 21467284] 
[122] Kryskalla J, Kern S, Gray D, Hauser P. Using dashboard technology to monitor overdose risk. Fed Prac 2014; pp. 8-14.

[123] Department of Veterans Affairs Viral Hepatitis: Treatment 2013. Retrieved from http://www.hepatitis.va.gov/patient/hcv/treat/single-page.asp 2015 [1/20/2015];

[124] Nguyen HA, Miller AI, Dieperink E, et al. Spectrum of disease in U.S. veteran patients with hepatitis C. Am J Gastroenterol 2002; 97(7): 1813-20. [PMID: 12135041]

[125] Johnson ME, Fisher DG, Fenaughty A, Theno SA, Hepatitis C. Hepatitis C virus and depression in drug users. Am J Gastroenterol 1998; 93(5): 785-9. [PMID: 9625128]

[126] Lehman CL, Cheung RC. Depression, anxiety, post-traumatic stress, and alcohol-related problems among veterans with chronic hepatitis C. Am J Gastroenterol 2002; 97(10): 2640-6.

[127] Loftis JM, Patterson AL, Wilhelm CJ, et al. Vulnerability to somatic symptoms of depression during interferon-alpha therapy for hepatitis C: a 16-week prospective study. J Psychosom Res 2013; 74(1): 57-63. [PMID: 23272989]

[128] Yoon JC, Crane PK, Ciechanowski PS, Harrington RD, Kitahata MM, Crane HM. Somatic symptoms and the association between hepatitis C infection and depression in HIV-infected patients. AIDS Care 2011; 23(10): 1208-18. [PMID: 21562994]

[129] Scheft H, Fontenette DC. Psychiatric barriers to readiness for treatment for hepatitis C Virus (HCV) infection among injection drug users: clinical experience of an addiction psychiatrist in the HIV-HCV coinfection clinic of a public health hospital. Clin Infect Dis 2005; 40(Suppl. 5): S292-6.

[PMID: 15768337]

[130] Knott A, Dieperink E, Willenbring ML, et al. Integrated psychiatric/medical care in a chronic hepatitis C clinic: effect on antiviral treatment evaluation and outcomes. Am J Gastroenterol 2006; 101(10): 2254-62. [PMID: 17032190]

[131] Sockalingam S, Abbey SE. Managing depression during hepatitis C treatment. Can J Psychiatry 2005; 54(9): 614-25.

[132] Loftis JM, Hauser P. Pain and opioid use in chronic liver disease: optimal treatment must address the mental health care needs of the patient. Dig Dis Sci 2013; 58(10): 2753-5. [PMID: 23959213]

[133] Hauser P, Kern S. Psychiatric and substance use disorders co-morbidities and hepatitis C: Diagnostic and treatment implications. World J Hepatol 2015; 7(15): 1921-35. [PMID: 26244067]

[134] a) Otsubo T, Miyaoka H, Kamija K, et al. Depression during interferon therapy in chronic hepatitis C patients -a prospective study. Sishin Shinkeigaku Zasshi. 1997 (99): 101-127. b) Hosoda S, Takimura H, Shibayama M, Kanamura H, Ikeda K, Kumada H. Psychiatric symptom related to interferon therapy for chronic hepatitis C: Clinical features and prognosis. Psychiatry Clin Neurosci 2000; 54: 565-72. [PMID: 11043807]

[135] Hosoda S, Takimura H, Shibayama M, Kanamura H, Ikeda K, Kumada H. Psychiatric symptoms related to interferon therapy for chronic hepatitis C: clinical features and prognosis. Psychiatry Clin Neurosci 2000; 54(5): 565-72. [PMID: 11043807]

[136] Mulder RT, Ang M, Chapman B, Ross A, Stevens IF, Edgar C. Interferon treatment is not associated with a worsening of psychiatric symptoms in patients with hepatitis C. J Gastroenterol Hepatol 2000; 15(3): 300-3. [PMID: 10764032]

[137] Gohier B, Goeb JL, Rannou-Dubas K, Fouchard I, Calès P, Garré JB. Hepatitis C, alpha interferon, anxiety and depression disorders: a prospective study of 71 patients. World J Biol Psychiatry 2003; 4(3): 115-8. [PMID: 12872204]

[138] Horikawa N, Yamazaki T, Izumi N, Uchihara M. Incidence and clinical course of major depression in patients with chronic hepatitis type C undergoing interferon-alpha therapy: a prospective study. Gen Hosp Psychiatry 2003; 25(1): 34-8. [PMID: 12583926]

[139] Raison CL, Borisov AS, Broadwell SD, et al. Depression during pegylated interferon-alpha plus ribavirin therapy: prevalence and prediction. J Clin Psychiatry 2005; 66(1): 41-8. [PMID: 15669887]

[140] Reichenberg A, Gorman JM, Dieterich DT. Interferon-induced depression and cognitive impairment in hepatitis C virus patients: a 72 week prospective study. AIDS 2005; 19(3)(Suppl. 3): S174-8. [PMID: 16251815]

[141] Dan AA, Martin LM, Crone C, et al. Depression, anemia and health-related quality of life in chronic hepatitis C. J Hepatol 2006; 44(3): 491-8. [PMID: 16427157] 
[142] Yoshida K, Alagbe O, Wang X, et al. Promoter polymorphisms of the interferon-alpha receptor gene and development of Interferon-induced depressive symptoms in patients with chronic hepatitis C: preliminary findings. Neuropsychobiology 2005; 52(2): 55-61. [PMID: 15990456]

[143] Wichers MC, Kenis G, Leue C, Koek G, Robaeys G, Maes M. Baseline immune activation as a risk factor for the onset of depression during interferon-alpha treatment. Biol Psychiatry 2006; 60(1): 77-9. [PMID: 16487941]

[144] Kraus MR, Al-Taie O, Schäfer A, Pfersdorff M, Lesch KP, Scheurlen M. Serotonin-1A receptor gene HTR1A variation predicts interferoninduced depression in chronic hepatitis C. Gastroenterology 2007; 132: 1279-86.(4) [PMID: 17408646]

[145] Laguno M, Blanch J, Murillas J, et al. Depressive symptoms after initiation of interferon therapy in human immunodeficiency virus-infected patients with chronic hepatitis C. Antivir Ther (Lond) 2004; 9(6): 905-9. [PMID: 15651749]

C Chereji et al. ; Licensee Bentham Open

This is an open access article licensed under the terms of the Creative Commons Attribution-Non-Commercial 4.0 International Public License (CC BY-NC 4.0) (https://creativecommons.org/licenses/by-nc/4.0/legalcode), which permits unrestricted, non-commercial use, distribution and reproduction in any medium, provided the work is properly cited. 